Article

\title{
Nipagin-Functionalized Porphyrazine and Phthalocyanine-Synthesis, Physicochemical Characterization and Toxicity Study after Deposition on Titanium Dioxide Nanoparticles P25
}

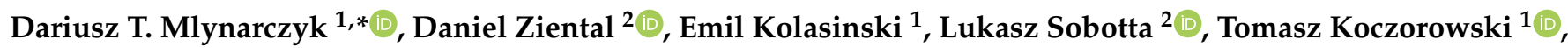 \\ Jadwiga Mielcarek ${ }^{2}$ and Tomasz Goslinski ${ }^{1}$ (D) \\ 1 Chair and Department of Chemical Technology of Drugs, Poznan University of Medical Sciences, \\ Grunwaldzka 6, 60-780 Poznań, Poland; emil.kolasinski95@gmail.com (E.K.); \\ tkoczorowski@ump.edu.pl (T.K.); tomasz.goslinski@ump.edu.pl (T.G.) \\ 2 Chair and Department of Inorganic and Analytical Chemistry, Poznan University of Medical Sciences, \\ Grunwaldzka 6, 60-780 Poznań, Poland; dziental@ump.edu.pl (D.Z.); 1sobotta@ump.edu.pl (L.S.); \\ jmielcar@ump.edu.pl (J.M.) \\ * Correspondence: mlynarczykd@ump.edu.pl; Tel.: +48-61-854-66-33; Fax: +48-61-854-66-39
}

Citation: Mlynarczyk, D.T.; Ziental, D.; Kolasinski, E.; Sobotta, L.; Koczorowski, T.; Mielcarek, J.; Goslinski, T. Nipagin-Functionalized Porphyrazine and PhthalocyanineSynthesis, Physicochemical

Characterization and Toxicity Study after Deposition on Titanium Dioxide Nanoparticles P25. Molecules 2021, 26, 2657. https://doi.org/10.3390/ molecules 26092657

Academic Editor: Augusto C. Tomé

Received: 18 March 2021

Accepted: 28 April 2021

Published: 1 May 2021

Publisher's Note: MDPI stays neutral with regard to jurisdictional claims in published maps and institutional affiliations.

Copyright: (c) 2021 by the authors. Licensee MDPI, Basel, Switzerland. This article is an open access article distributed under the terms and conditions of the Creative Commons Attribution (CC BY) license (https:// creativecommons.org/licenses/by/ $4.0 /)$.

\begin{abstract}
Aza-porphyrinoids exhibit distinct spectral properties in UV-Vis, and they are studied in applications such as photosensitizers in medicine and catalysts in technology. The use of appropriate peripheral substituents allows the modulation of their physicochemical properties. Phthalocyanine and sulfanyl porphyrazine octa-substituted with 4-(butoxycarbonyl)phenyloxy moieties were synthesized and characterized using UV-Vis and NMR spectroscopy, as well as mass spectrometry. A comparison of porphyrazine with phthalocyanine aza-porphyrinoids revealed that phthalocyanine macrocycle exhibits higher singlet oxygen generation quantum yields, reaching the value of 0.29 in DMF. After both macrocycles had been deposited on titanium dioxide nanoparticles P25, the cytotoxicities and photocytotoxicities of the prepared materials were studied using a Microtox ${ }^{\circledR}$ acute toxicity test. The highest cytotoxicity occurred after irradiation with a red light for the material composed of phthalocyanine deposited on titania nanoparticles.
\end{abstract}

Keywords: phthalocyanine; porphyrazine; Linstead macrocyclization; Microtox; singlet oxygen; titanium dioxide

\section{Introduction}

Porphyrazines (Pzs) are synthetic aza-analogues of porphyrins, which do not occur naturally [1]. Their unique physicochemical properties result from macrocyclic ring presence, composed of four pyrrole rings linked by azamethine bridges. Pzs that contain four benzo units annulated to the ring are termed phthalocyanines (Pcs). The advantageous properties of Pzs and Pcs include their electrochemical activity, strong light absorption in the UV-Vis range, and the ability to mediate singlet oxygen production, which is beneficial for photodynamic therapy (PDT) applications. All of the abovementioned characteristics allow the application of Pzs and Pcs not only in medicine, but also as sensors and catalysts in chemistry and technology.

Unsubstituted $\mathrm{Pz}$ and Pc rings are non-polar and prone to aggregation, which adversely affects some of their properties, such as solubility and singlet oxygen generation. This is the primary reason why many new aza-porphyrinoids with diverse substituents at peripheral positions have been synthesized. It has been noted that, among new $\mathrm{Pz}$ derivatives, those that are sulfanyl-based exhibit good solubility, interesting optical, photochemical, and electrochemical properties [2-6], as well as high photocytotoxicities against cancer cells [7]. Further, 4-hydroxyphenyl moiety has been repeatedly described in conjunction with various aza-porphyrinoids as a peripheral substituent or a linker allowing 
it to obtain more rebuild molecules. An interesting study in this field was presented by Wöhrle et al., who synthesized a metal-free Pc substituted in peripheral positions with 4-carbonylphenyloxy groups [8]. Recently, Taşkın et al. achieved silicon phthalocyanines (SiPcs), substituted axially with different methyl, ethyl, prop-1-yl, and but-1-yl esters of 4-hydroxybenzoic acid [9]. The resulting series of SiPcs was evaluated in terms of photocytotoxicity against Staphylococcus mutants, a known dental pathogen. It is worth noting that SiPc substituted with prop-1-ylparaben moiety was found to be the most active against the bacteria's planktonic form, whereas no significant activity against the biofilm form was observed. In another study, Masilela et al. synthesized an unsymmetrical zinc(II) phthalocyanine $(\mathrm{ZnPc})$ with one nipagin substituent and six 2-(diethylamino)ethylsulfanyl groups in the periphery [10]. This $\mathrm{Pz}$ was then used to produce polystyrene nanofibers that were tested for their photodynamic activity against Staphylococcus aureus and found to be effective. Lately, Vashurin et al. reported the synthesis of symmetrical $\mathrm{A}_{4}$ type cobalt phthalocyanines tetra- or octa-substituted with nipagins in $\beta$-positions $[11,12]$. The macrocycles were then successfully tested as photocatalysts in the oxidation of sulfur-containing organic compounds.

Therefore, the presence of an aromatic macrocyclic ring of a highly hydrophobic nature results in low solubility of such molecules in aqueous systems and, thus, in biological fluids. Many studies have presented the use of specific carriers modifying the properties of porphyrinoids and allowing their application in stable suspensions in water. This method simultaneously increases their application in targeted therapy whilst reducing their intrinsic toxicity [13-15]. The delivery agents tested to the greatest extent are liposomes [16,17], metal and metal oxide nanoparticles [18-20], and polymeric nanomaterials [21]. Various connections of porphyrinoids with nanoparticles and supramolecules have been studied so far. For example, Baugh et al. synthesized a series of Pcs, including unsymmetrical $\mathrm{A}_{3} \mathrm{~B}$ type Pc containing 4-hydroxybenzoic acid moieties in one of their $\beta$-positions and tert-butylphenyl or functionalized ketals in the other three positions, and studied the action of the system after irradiation [22]. In another study, Rotas et al., synthesized silicon Pc functionalized with tert-butyl groups in the periphery and axially substituted with one or two azafullerenes via 4-hydroxybenzoic linkers, and studied the spectral properties of such a system [23]. Mphuthi et al. obtained a material composed among others of metal-free $\mathrm{Pc}$ and $\mathrm{Fe}_{3} \mathrm{O}_{4}$ nanoparticles, which enabled and potentiated the sensing of dopamine [24]. In another study, ceria nanoparticles were used as a support for the 5,10,15,20-tetrakis(4carboxyphenyl) porphyrin [25]. The obtained hybrid material was studied as a catalyst mimicking peroxidase activity, and revealed its activity for glucose detection. Dube et al. combined the designed Pcs with $\mathrm{Fe}_{3} \mathrm{O}_{4} / \mathrm{SiO}_{2}$ nanoparticles with an amide bond using an aminopropylsilyl linker [26]. The proposed approach gave access to functionalized nanoparticles of potent antimicrobial activity. In another study, photoactivity increase was also observed for polymerized iron phthalocyanine combined with zinc oxide nanoparticles. The obtained material revealed catalytic activity in the photo-Fenton reaction of potential utility for the efficient decomposition of emerging environmental pollutants.

Among other nanoparticles, titanium dioxide $\left(\mathrm{TiO}_{2}\right)$ exhibits special properties. These nanostructures can act as carriers for porphyrinoids or can potentiate the effectiveness of irradiated photosensitizers due to the ability to transfer energy between $\mathrm{TiO}_{2}$ and a photoactive molecule [27]. Moreover, $\mathrm{TiO}_{2}$ nanoparticles reveal photoactivity only when they are irradiated with UV light and, therefore, are considered relatively non-toxic [28].

In the presented study, Pc and sulfanyl Pz substituted with eight 4-(butoxycarbonyl) phenyloxy moieties were obtained and characterized using UV-Vis and nuclear magnetic resonance (NMR) spectroscopy, mass spectrometry (MS), as well as subjected to photochemical studies in order to determine singlet oxygen quantum yield generation. Both macrocycles were deposited on commercially available P25 titania nanoparticles, and the toxicities of obtained materials were assessed using a Microtox ${ }^{\circledR}$ acute toxicity test. 


\section{Results and Discussion}

\subsection{Synthesis and Characterization}

The synthetic route leading to new macrocycles appended with 4-hydroxybenzoic moieties started from the alkylation reaction of ethyl 4-hydroxybenzoate with 1,4-dibromobutane (Scheme 1). The obtained ethyl 4-(4-bromobutoxy)benzoate (1) was then used in the syntheses of phthalonitrile derivative $\mathbf{2}$, that was a precursor of the Pc. Thus, $\mathbf{1}$ was stirred at room temperature with 3,6-dihydroxybenzene-1,2-dicarbonitrile in $N, N$-dimethylformamide (DMF) with $\mathrm{K}_{2} \mathrm{CO}_{3}$ for $20 \mathrm{~h}$ to give 2 in a $68 \%$ yield after purification. Next, phthalonitrile derivative 2 was used in the Linstead macrocyclization reaction in butan-1-ol using magnesium butan-1-olate as a base towards Pc 3 with a low $2.4 \%$ yield by adapting a previously published methodology $[29,30]$. During cyclotetramerization, the transesterification reaction of ethyl to butyl moieties took place within the ester moieties.

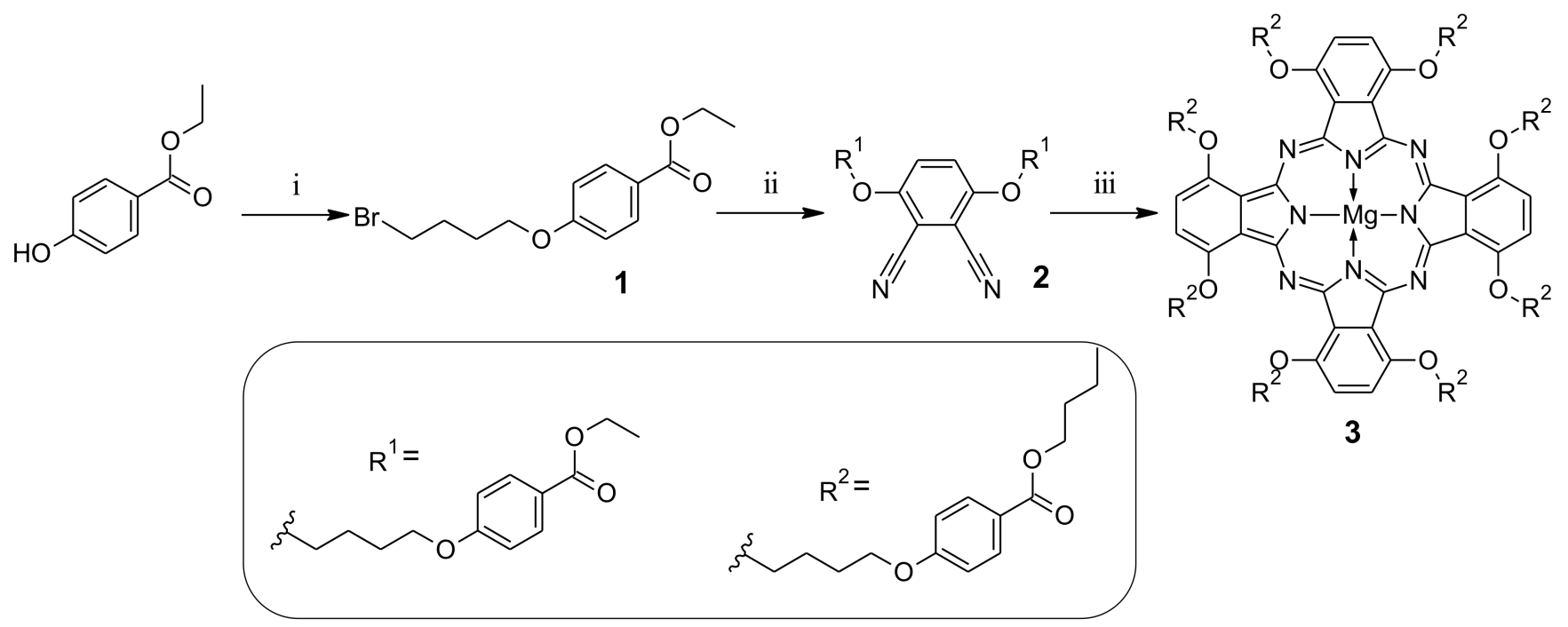

Scheme 1. Synthetic route leading to symmetrical phthalocyanine derivative 3: (i) 1,4-dibromobutane, $\mathrm{K}_{2} \mathrm{CO}_{3}, \mathrm{DMF}, \mathrm{rt}$, $72 \mathrm{~h}$; (ii) 3,6-dihydroxybenzene-1,2-dicarbonitrile, $\mathrm{K}_{2} \mathrm{CO}_{3}, \mathrm{DMF}, \mathrm{rt}, 20 \mathrm{~h}$; (iii) $\mathrm{Mg}(\mathrm{BuO})_{2}, \mathrm{BuOH}, 120^{\circ} \mathrm{C}, 20 \mathrm{~h}$.

Parallelly, compound 1 was subjected to the alkylation reaction with dimercaptomaleonitrile sodium salt and potassium carbonate in DMF at $50{ }^{\circ} \mathrm{C}$ for $20 \mathrm{~h}$ (Scheme 2), which allowed us to synthesize maleonitrile derivative 4 in a $49.5 \%$ yield. Next, compound 4 was used in the macrocyclization reaction towards sulfanyl Pz derivative by adapting a previously published methodology [31]. The macrocyclic product was characterized by NMR and MS techniques. Analysis indicated that the ethyl ester moieties underwent only partial transesterification (see Figures S11-S13 in the Supplementary Materials). It is worth noting that the but-1-yl ester substituted Pz derivative was also not obtained during the macrocyclization reaction when an eightfold molar excess of magnesium butan-1-olate was applied, or when the macrocyclic product with mixed ethyl/but-1-yl periphery was refluxed in butan-1-ol (also in the presence of 1,8-diazabicyclo(5.4.0)undec-7-ene - DBU as a base).

As the butyl and ethyl groups could not be unambiguously assigned, and the HPLC results gave clear information that there is only one compound present in the sample, a different synthetic approach was proposed. But-1-yl 4-hydroxybenzoate was proposed as a starting material in place of ethyl 4-hydroxybenzoate $\mathbf{1}$ to avoid the problem of transesterification reaction (Scheme 3). 


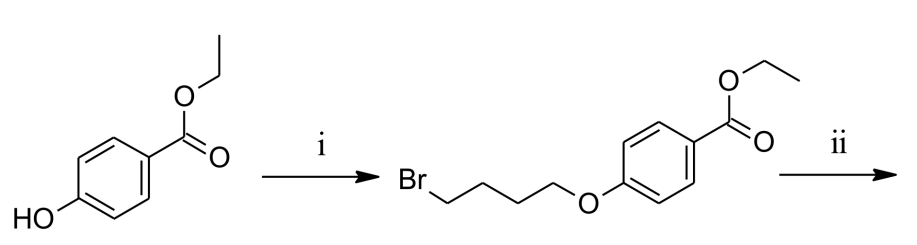

1

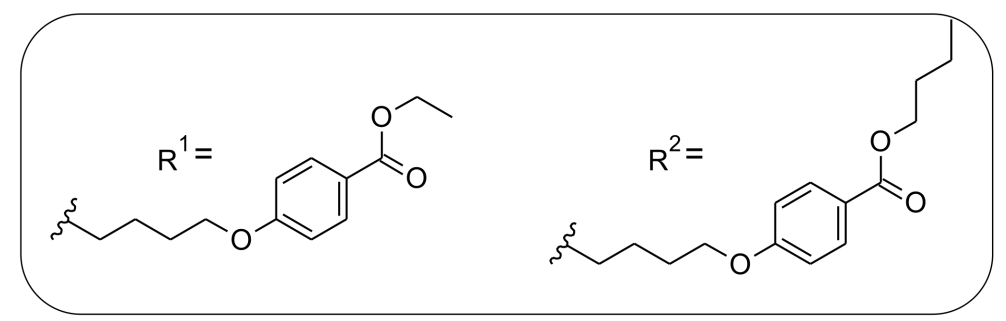

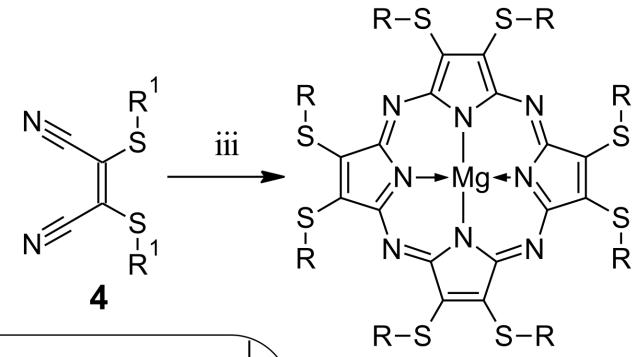

$\mathbf{R}=\mathbf{R}^{1}$ and $\mathbf{R}^{2}$ unsymmetrical species with peripheral ethyl or but-1-yl ester substituents

Scheme 2. Synthetic route leading to sulfanyl porphyrazine: (i) 1,4-dibromobutane, $\mathrm{K}_{2} \mathrm{CO}_{3}, \mathrm{DMF}$, rt, $72 \mathrm{~h}$; (ii) dimercaptomaleonitrile sodium salt hydrate, $\mathrm{K}_{2} \mathrm{CO}_{3}, \mathrm{DMF}, 50{ }^{\circ} \mathrm{C}, 20 \mathrm{~h}$; (iii) $\mathrm{Mg}(\mathrm{BuO})_{2}, \mathrm{BuOH}, 120{ }^{\circ} \mathrm{C}, 20 \mathrm{~h}$.

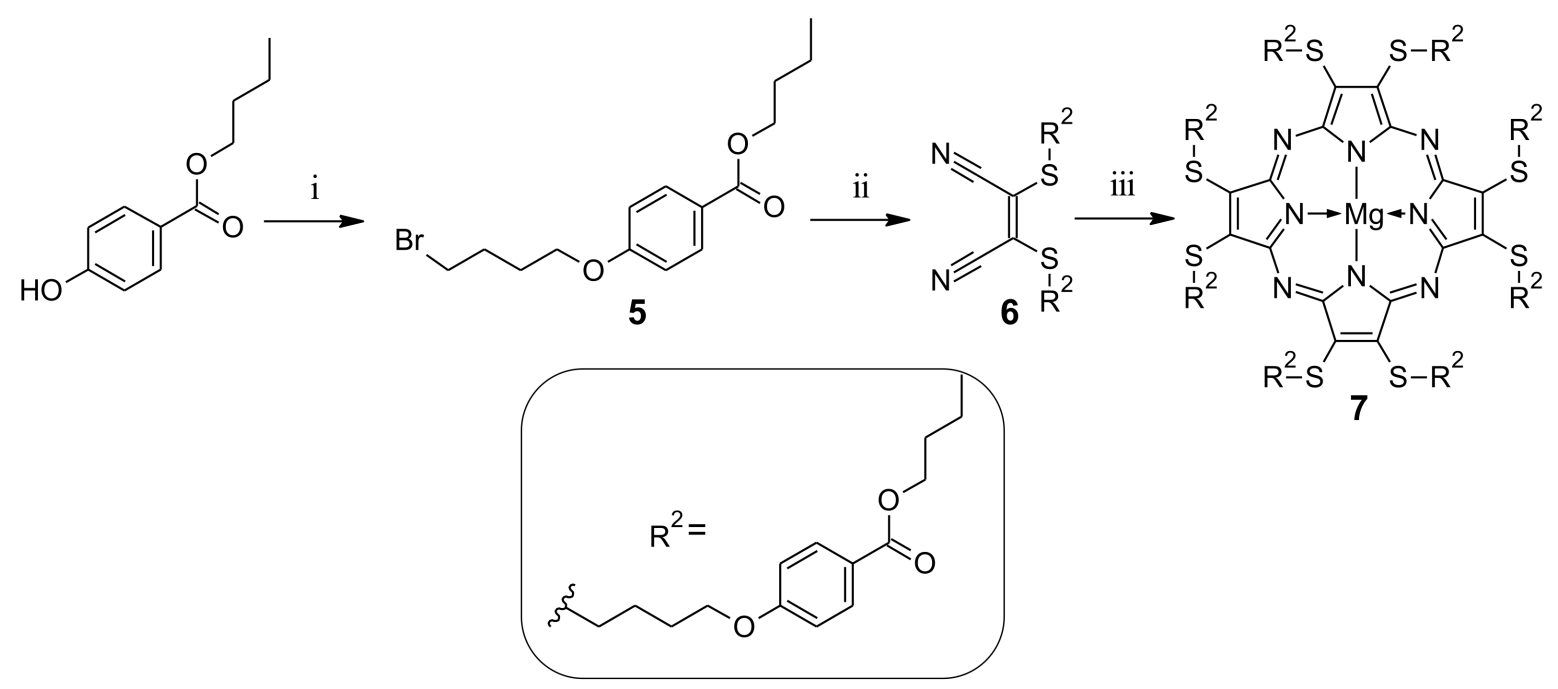

Scheme 3. Synthetic route leading to novel sulfanyl porphyrazine 7: (i) 1,4-dibromobutane, $\mathrm{K}_{2} \mathrm{CO}_{3}, \mathrm{DMF}, \mathrm{rt}, 72 \mathrm{~h}$; (ii) dimercaptomaleonitrile sodium salt hydrate, $\mathrm{K}_{2} \mathrm{CO}_{3}, \mathrm{DMF}, 50{ }^{\circ} \mathrm{C}, 20 \mathrm{~h}$; (iii) $\mathrm{Mg}(\mathrm{BuO})_{2}, \mathrm{BuOH}, 120{ }^{\circ} \mathrm{C}, 20 \mathrm{~h}$.

Following the reaction conditions elaborated for 1, but-1-yl 4-hydroxybenzoate was used in the alkylation reaction, with an excess of 1,4-dibromobutane towards compound 5. This product was isolated after column chromatography with an average $25 \%$ yield. It was because of the formation of the dimeric side product 5D with a $43 \%$ yield (see Figures S16-S17). The formation of dimers in similar conditions has also been described by other authors in the literature [32]. Next, $\mathbf{5}$ was purified using column chromatography and subjected to the alkylation reaction with dimercaptomaleonitrile sodium salt hydrate towards dimercaptomaleonitrile derivative $\mathbf{6}$. Dimercaptomaleonitrile derivative $\mathbf{6}$ was applied in the macrocyclization reaction with magnesium butan-1-olate in refluxing butan1-ol, leading to sulfanyl Pz 7 in a moderate $32 \%$ yield. The course of macrocyclization reaction, with the use of but-1-yl ester of mercaptomaleonitrile derivative, prompted us to reconsider the alternative synthetic approach for the previously obtained Pc 3 (Scheme 4). Thus, derivative 5 was subjected to the alkylation reaction with 3,6-dihydroxybenzene-1,2dicarbonitrile towards phthalonitrile derivative 8 , which was isolated with a $76 \%$ yield. Phthalonitrile derivative 8 was then used in the Linstead macrocyclization reaction, with magnesium butan-1-olate as a base in butan-1-ol to give the desired Pc macrocycle 3 . The 
macrocyclization reaction with $\mathbf{8}$ was much more efficient than with the previously applied phthalonitrile derivative 2, and led to Pc 3 in a moderate $34 \%$ yield.

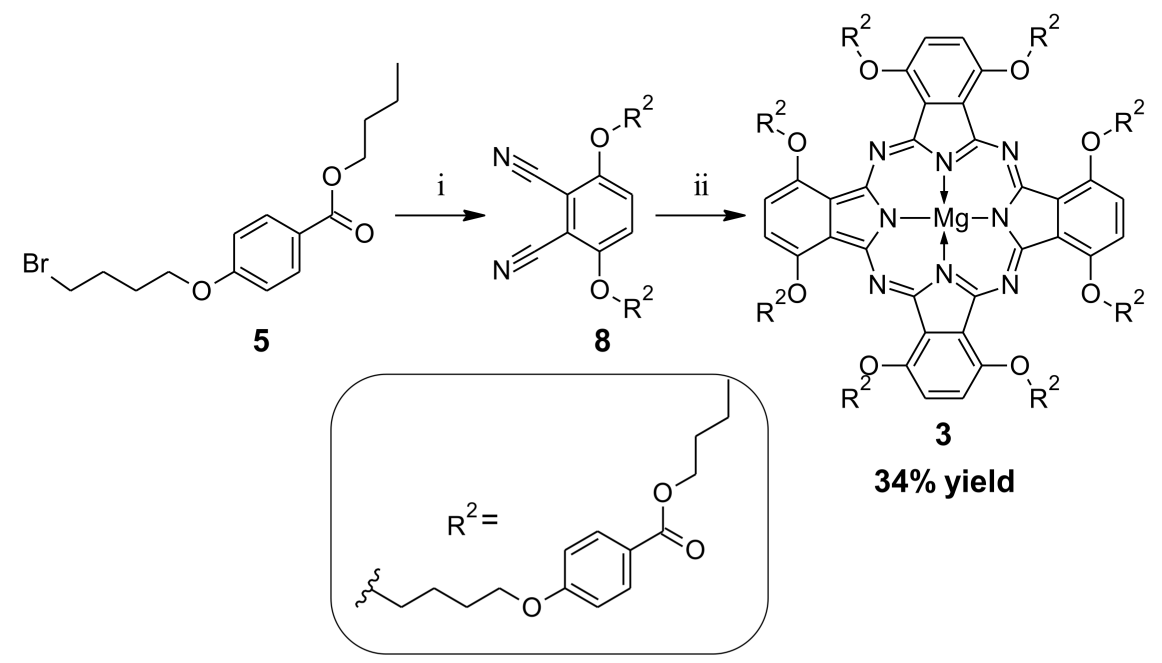

Scheme 4. Alternative synthetic route leading to 3: (i) 3,6-dihydroxybenzene-1,2-dicarbonitrile, $\mathrm{K}_{2} \mathrm{CO}_{3}, \mathrm{DMF}$, rt, $20 \mathrm{~h}$; (ii) $\mathrm{Mg}(\mathrm{BuO})_{2}, \mathrm{BuOH}, 120^{\circ} \mathrm{C}, 20 \mathrm{~h}$.

Pc 3 and Pz 7, were soluble in organic solvents, such as dichloromethane (DCM), toluene, tetrahydrofuran, acetonitrile, acetone, DMF, dimethyl sulfoxide (DMSO), and pyridine. Neither of them were soluble in methanol $(\mathrm{MeOH})$ and other polar solvents. Differences were observed when attempting to precipitate the macrocycles from DCM by the slow addition of $\mathrm{MeOH}$. At the time, 3 formed a green precipitate, as expected, whereas 7 formed a stable non-transparent blue suspension and could not be purified in this way.

We also attempted to synthesize $\mathrm{A}_{3} \mathrm{~B}$ type macrocycles by using either phthalonitrile or maleonitrile derivatives $2,4,6,8$, and an excessive amount of 1,2-dicyanobenzene (tenfold $\mathrm{mol} / \mathrm{mol}$ ) each time. In each case, only the formation of a tiny amount of $\mathrm{A}_{3} \mathrm{~B}$ products was observed in the matrix-assisted laser desorption/ionization (MALDI) mass spectra, but the estimated yields were about ten times lower than for symmetrical analogues. Moreover, $\mathrm{A}_{3} \mathrm{~B}$ products could not be isolated in their pure form and the NMR spectra were of low quality (for more information, please refer to Figures S30-S31).

All compounds were subjected to detailed NMR studies (see Figures S3-S23). In the ${ }^{1} \mathrm{H}$ NMR spectrum of $\mathbf{1}$, signals at 1.29 and 4.25 ppm were assigned to ethyl ester $\mathrm{CH}_{3}$ and $\mathrm{CH}_{2}$ protons, respectively. The other aliphatic part of the chain, namely 4-bromobutoxy moiety, appeared as four signals at 3.59, 1.96, 1.84 and 4.07 ppm for $\mathrm{CH}_{2}$ groups, consecutively, from $\mathrm{BrCH}_{2}$ to $\mathrm{CH}_{2} \mathrm{O}$, which correlate well in the ${ }^{1} \mathrm{H}-{ }^{1} \mathrm{H}$ correlation spectroscopy (COSY) NMR spectrum. The characteristic signals from the $p$-substituted benzene ring protons were found at 7.03 and $7.90 \mathrm{ppm}$. Derivative 2 shares a similar structural motif with signals at 4.25 and 1.30 ppm assigned to the ethyl chain, and signals at 4.14, 1.91 and 4.23 ppm prescribed to the linker group. The para-substituted benzene aromatic protons were found at 7.02 and $7.89 \mathrm{ppm}$. The dicyanobenzene aromatic protons appeared as a singlet at $7.61 \mathrm{ppm}$. The carbon atom signals appearing in the ${ }^{13} \mathrm{C}$ NMR spectrum were assigned with the use of ${ }^{1} \mathrm{H}-{ }^{13} \mathrm{C}$ heteronuclear single quantum coherence (HSQC) and ${ }^{1} \mathrm{H}-{ }^{13} \mathrm{C}$ heteronuclear multiple-bond correlation spectroscopy (HMBC) spectra for cyano group at $113.5 \mathrm{ppm}$, dicyanobenzene at 102.8, 120.5, $154.8 \mathrm{ppm}$, para-substituted benzene at $114.4,122.0,131.1,162.4 \mathrm{ppm}$, and carboxylic group at $165.4 \mathrm{ppm}$. In the ${ }^{1} \mathrm{H}$ and ${ }^{1} \mathrm{H}-{ }^{1} \mathrm{H}$ COSY NMR spectra recorded for Pc 3, the transesterification reaction within ester moieties was clearly confirmed. Butyl ester protons appeared at $0.85,1.34,1.60$, and 4.29 ppm, while butylene linker part protons were found at 4.26, 2.31, 2.52, and 5.24 ppm. Eight aromatic protons of the Pc ring appeared as a singlet peak at $7.90 \mathrm{ppm}$. The characteristic aromatic protons from nipagin moieties were found at 8.09 and $7.04 \mathrm{ppm}$. The ${ }^{1} \mathrm{H}$ NMR spectrum 
of 4 revealed two groups of signals, resulting from the ethyl group at 1.29 and 4.26 ppm, and from butylene moiety at $4.05,1.82$, and 3.23 ppm. The $\mathrm{C} 2$ and $\mathrm{C} 3$ linker $\mathrm{CH}_{2}$ groups protons appeared as a multiplet in the ${ }^{1} \mathrm{H}$ NMR spectrum at $1.82 \mathrm{ppm}$ due to overlapped signals - this multiplet signal correlated in the ${ }^{1} \mathrm{H}-{ }^{13} \mathrm{C}$ HSQC spectrum with two carbon nuclei signals at 26.1 and $27.1 \mathrm{ppm}$. Benzene ring protons were assigned to signals at 6.99 and 7.89 ppm.

In the ${ }^{1} \mathrm{H}$ NMR spectrum of 5 , many similarities to its ethyl analogue 1 were found. The group of signals at $0.86,1.35,1.64$, and 4.33 ppm was assigned to the butyl protons, while the signals from the butylene linker were found at 4.17, 2.04, 2.41 and $5.51 \mathrm{ppm}$. The aromatic signals at 7.16 and 8.18 ppm confirming the para-substitution come from the protons within the benzene ring. Similarly, in the ${ }^{1} \mathrm{H}$ NMR spectrum of 6 , two groups of proton signals can be distinguished, correlating separately in the ${ }^{1} \mathrm{H}-{ }^{1} \mathrm{H}$ COSY spectrum. It concerns signals at $0.92,1.40,1.67$ and 4.22 ppm from the butyl ester aliphatic hydrogen atoms and 4.07,1.83, and 3.25 ppm from the butylene linker $\mathrm{CH}_{2}$ groups. The characteristic signals coming from the para-substituted benzene ring were found at 7.00 and $7.88 \mathrm{ppm}$. In the ${ }^{1} \mathrm{H}$ NMR spectrum of 7 , two groups of signals were distinguished at $0.92,1.39,1.66$, and $4.21 \mathrm{ppm}$, confirming the presence of butyl ester protons, and at 4.06, 1.83, and $3.24 \mathrm{ppm}$, coming from the butylene linker. Signals of protons from the para-substituted benzene ring were found at 6.99 and $7.87 \mathrm{ppm}$. The ${ }^{13} \mathrm{C}$ NMR spectrum revealed macrocyclic ring signals at 112.4 and $121.2 \mathrm{ppm}$. In the ${ }^{1} \mathrm{H}$ NMR spectrum of 8 , a group of aliphatic protons correlating in the ${ }^{1} \mathrm{H}-{ }^{1} \mathrm{H}$ COSY at $0.90,1.38,1.65$, and 4.20 ppm was detected, and which was assigned to butyl ester moiety. Another group of signals, appearing at 4.12, 1.89 and $4.20 \mathrm{ppm}$, was assigned to the butylene linker. Three signals in the aromatic part of macrocycle 8 were prescribed to the nipagin ring protons (signals at 7.00 and $7.85 \mathrm{ppm}$ ) and the 1,2-dicyanobenzene ring (signal at $7.59 \mathrm{ppm}$ ).

The ${ }^{1} \mathrm{H}$ and ${ }^{13} \mathrm{C}$ NMR spectra, as well as the correlations found in the ${ }^{1} \mathrm{H}-{ }^{1} \mathrm{H}$ COSY, ${ }^{1} \mathrm{H}-{ }^{13} \mathrm{C}$ HSQC, and ${ }^{1} \mathrm{H}_{-}{ }^{13} \mathrm{C} \mathrm{HMBC}$ spectra for all compounds discussed in this paper, are presented in the Supplementary Materials.

\section{2. $\mathrm{TiO}_{2}$ Deposition and Characterization}

Titanium dioxide, mostly a mixture of crystal phases of anatase and rutile, known as P25, has been utilized in many studies as a carrier for photosensitizers [33,34]. It forms stable dispersions for compounds that are insoluble in water and, thus, can be tested and potentially applied. The surface of titanium dioxide and other oxides may be functionalized with porphyrinoids following various methods. Molecules substituted with anchoring groups interact with the surface of the nanoparticles, which results in stable bond formation and allows for energy transfer between both components [35]. Various macrocycles can also be embedded on the formed surface of the oxide nanoparticles during their synthesis [36]. Alternatively, the nanoparticles can be appended with various linkers (i.e., by silylation), which allows for covalent bond formation between the nanoparticles and the photosensitizers [26]. Finally, the interactions could consist in weak bonds between the photosensitizers and the unmodified surface of the nanoparticles, or the chemical groups present on their surfaces after functionalization, i.e., hydrophobic interactions with the long PEG chains [37]. In the presented study, titania nanoparticles with a plethora of hydroxyl surface groups were applied to influence their adsorption properties and enable the formation of hydrogen bonds [38]. The materials were prepared by depositing either 3 or 7 on the surface of $\mathrm{TiO}_{2}$ nanoparticles. The solutions of macrocycles were added to titania suspension, sonicated, and mixed until the solvent evaporated, yielding 3@P25 and 7@P25, respectively. The resulting materials contain 10\% (w/w) of the macrocycles. The particle sizes of the obtained materials were assessed using nanoparticle tracking analysis and compared to the values obtained for unmodified $\mathrm{TiO}_{2}$ nanoparticles. The results are summarized in Table 1. 
Table 1. The particle size distribution of P25, 3@P25 and 7@P25.

\begin{tabular}{ccc}
\hline Material & Measured Particle Size [nm] & ${\text { Polydispersity } \text { Index }^{\mathbf{a}}}^{{ }^{\mathbf{2}}}$ \\
\hline P25 & $132.1 \pm 85.1$ & 0.42 \\
\hline 3@P25 & $148.4 \pm 99.3$ & 0.45 \\
\hline 7@P25 & $159.1 \pm 101.2$ & 0.40 \\
\hline
\end{tabular}

a calculated according to the formula PDI $=(\mathrm{SD} / \text { mean diameter })^{2}$ [39].

Based on the particle size values measured, strong agglomeration of the nanoparticles was observed. The mean hydrodynamic particle sizes of 3@P25 $(148.4 \pm 99.3 \mathrm{~nm})$ and 7@P25 (159.1 $\pm 101.2 \mathrm{~nm})$ were similar to unmodified P25 $(132.1 \pm 85.1 \mathrm{~nm})$, which suggests that the deposition of the macrocycles had only a negligible effect on the titania nanoparticles. Additionally, the calculated polydispersity indices values exceed 0.2 , deeming them polydisperse materials [39]. These phenomena may be attributed to the fact that no stabilization was applied to the materials, including applying of surfactants or moieties capable of electrostatic interactions. Nevertheless, such stabilizers could induce some toxic effects of nanoparticles, which are undesirable when the materials could be considered for photodynamic therapy.

\subsection{Spectral and Photochemical Studies}

\subsubsection{Absorption and Fluorescence}

Each of the studied macrocyclic compounds possesses two characteristic absorption bands- the $B$ band in the blue region and the $Q$ band in the red region of the UV-Vis spectrum. For macrocycle 3, a typical Pc absorption spectrum profile (Figure 1a) was observed-B band with a low molar absorption coefficient $(\varepsilon)$ and an intensive sharp $Q$ band. An assessment of the effects of different solvents on the UV-Vis absorption properties of 3 was performed. In the acidic solvents mixture composed of $1 \%$ acetic acid $(\mathrm{AcOH})$ in dichloromethane, the splitting of the $Q$ band was noted (this process was reversible after adding a base), whereas, in basic pyridine, the $Q$ band remained unsplit (Figure 1a). The observed effects can be explained by the protonation of phthalocyanine meso nitrogen atoms [40].

In the UV-Vis absorption spectrum of Pz 7, typical and intense B and Q bands were noted. Interestingly, in all studied solvents containing 7 , the $Q$ band remained unsplit (Figure 1b). This observation is in agreement with the data collected by Khelevina and Malyasova, who reported that Pzs reveal low basicity and, therefore, a high concentration of acid has to be used to induce their protonation [41].

In the emission study of macrocycles 3 and 7 , only Pc 3 presented weak emission properties, with the quantum yields $\left(\Phi_{\mathrm{FL}}\right)$ equal to 0.007 and 0.002 in DMF and DMSO, respectively. The drop in $\Phi_{\mathrm{FL}}$ values noted for 7 , in comparison to the unsubstituted magnesium(II) phthalocyanine (33-fold in DMF and 91-fold in DMSO [42,43]), could be explained by a more developed aromatic periphery in case of Pcs. It has been reported by Kobayashi and co-workers that substitution of $\mathrm{Pc}$ at $\alpha$ positions (non-peripheral) impacts a fluorescence yield [44]. In the case of Pc 3 , the solvatochromic-like effects [45,46] were observed, which was not the case for Pz 7. Monomeric form of $\mathbf{3}$ with a sharp and an intense $\mathrm{Q}$ band represents a green color (see Figures 1 and 2). Interestingly, in the UV-Vis profiles of 3 recorded in the dichloromethane, acetone and ethyl acetate a split, and a lowering of the $Q$ band intensity was observed. In these solvents, the Pc presented colors from brown in dichloromethane to rotten green in acetone or ethyl acetate. It proves that the extended aromatic ring of $\mathrm{Pc}$, in comparison to the $\mathrm{Pz}$ one, displays a strong solvatochromism, which is further reflected by changes in colors in the applied solvents. It can be also caused by a well-known, and reported in the literature, $\pi-\pi$ stacking between molecules, including magnesium(II) phthalocyanines [40]. In the acidic conditions (dichloromethane with $1 \%$ of acetic acid), the protonation of macrocycle 3 was observed in the UV-Vis, which manifested 
by the splitting of the $Q$ band to three counterparts (see Figure 1) and the dark-red color of the solution.
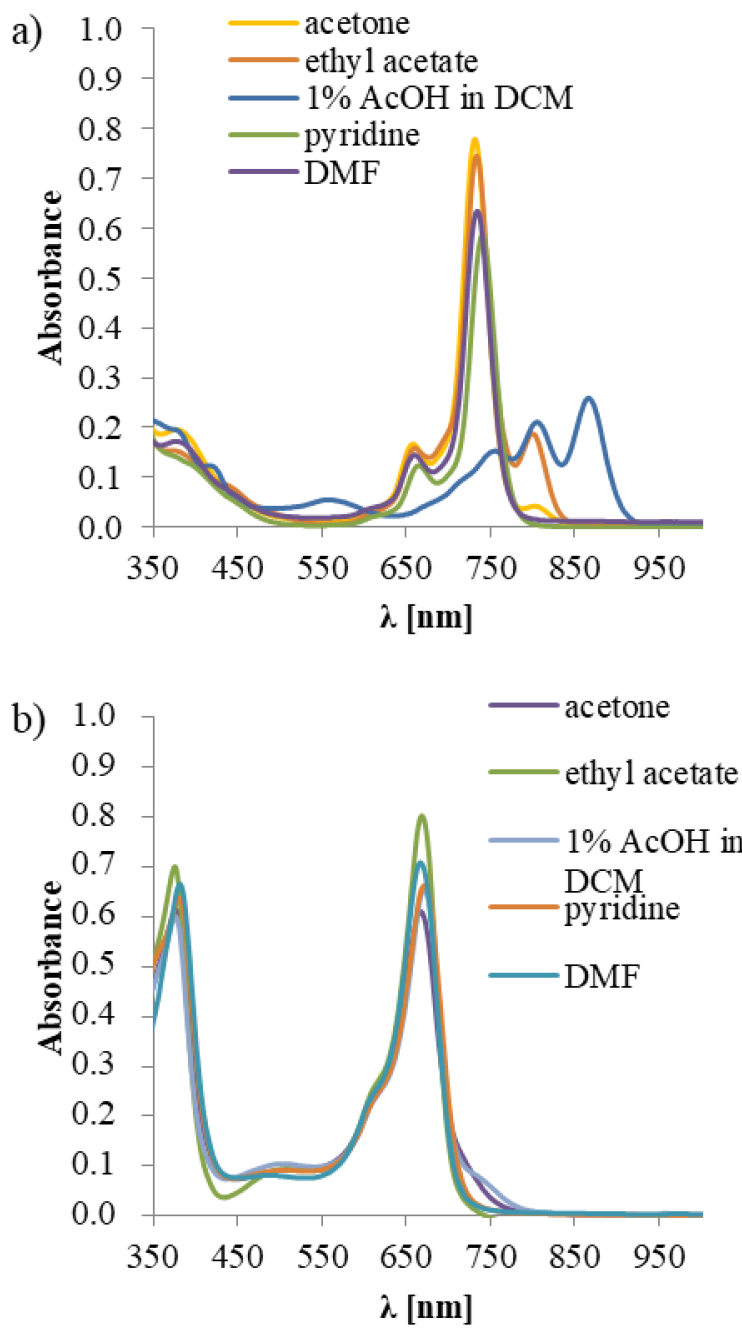

Figure 1. Solvatochromic effects observed in the UV-Vis spectra in various solvents for (a) 3; (b) 7; $\mathrm{AcOH}$ - acetic acid, DCM-dichloromethane, DMF-N,N-dimethylformamide.

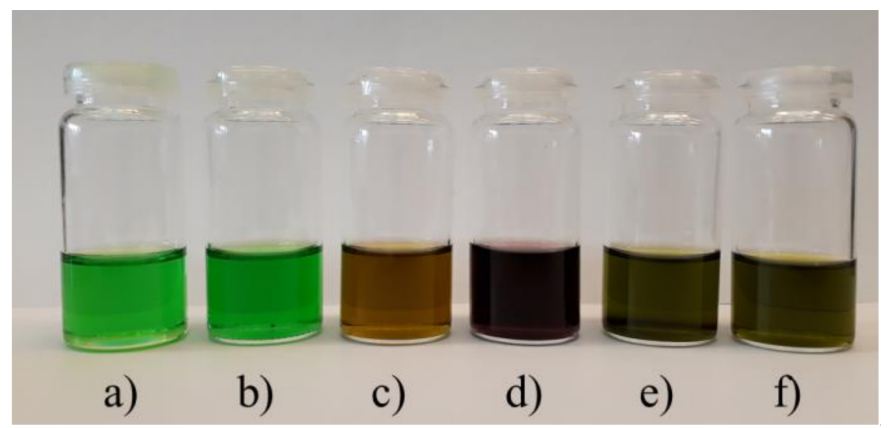

Figure 2. Effect of solvents used on the color of the solution of 3: (a) pyridine, (b) N,Ndimethylformamide, (c) dichloromethane, (d) dichloromethane $+1 \%$ of acetic acid, (e) acetone, (f) ethyl acetate.

\subsubsection{Singlet Oxygen Formation}

Singlet oxygen $\left({ }^{1} \mathrm{O}_{2}\right)$ is a crucial factor appearing in a type II photodynamic reaction as the result of interaction between light, molecular oxygen, and photosensitizer, and which can be considered as an energy conversion platform. The active oxygen form belongs 
to reactive oxygen species and is responsible for the effects observed in PDT of cancer, as well as against bacteria and other pathogens. Both studied macrocyclic compounds were able to mediate singlet oxygen generation, which was exemplified by singlet oxygen quantum yield values $\left(\Phi_{\Delta}\right)$ obtained during measurements performed in various solvents. The herein reported Pc 3 was a more efficient ${ }^{1} \mathrm{O}_{2}$ generator, with the $\Phi_{\Delta}$ equal to 0.29 and 0.13 in DMF and DMSO, respectively, in comparison to Pz 7, which revealed low $\Phi_{\Delta}$ values equal to 0.02 and 0.09 in DMF and DMSO, respectively. These $\Phi_{\Delta}$ values were in agreement with previous studies, in which phthalocyanines were found to be more efficient singlet oxygen generators compared to porphyrazines [47,48], especially sulfanyl porphyrazines [7]. Pc 3 revealed a lower singlet oxygen formation quantum yield in comparison to the reference compound-unsubstituted ZnPc. This could be related to the presence of developed substituents in its non-peripheral positions, which might hamper access of molecular oxygen to the macrocyclic core, whose direct interaction is necessary for ${ }^{1} \mathrm{O}_{2}$ formation [49]. A similar phenomenon was noted for Pc 9 (Figure 3) [50]. Due to the presence of large substituents, Pz 7 revealed a decrease in the quantum yield, which was linked to steric hindrance and limited oxygen access to the macrocyclic core. The lowering of the $\Phi_{\Delta}$ value can be clearly seen by comparison of $7\left(\Phi_{\Delta}=0.02\right.$, Table 2$)$ and previously reported $\mathrm{Pz} 10\left(\Phi_{\Delta}=0.14\right)$ [48]. The influence of sulfur atoms constituting a bridge between the macrocyclic ring and peripheral substituents should also be mentioned. According to the literature data, the presence of a sulfur atom directly linked to the $\mathrm{Pz}$ core results in a strong decrease of singlet oxygen formation yield [51,52]. Lately, we have reported sulfanyl tribenzoporphyrazines bearing isophthaloxy moiety $\mathbf{1 1}$, which was found to generate singlet oxygen with a much lower yield at 0.05 in DMF [42], in comparison to Pc 3, with $\Phi_{\Delta}$ equal to 0.29 , studied here. Measurements performed in DMSO revealed a slighter difference in the values of singlet oxygen generation at 0.13 vs. 0.08 [42] for 3 and 11, respectively. This observation could be explained by possible quenching of the excited states by $\pi-\pi$ interactions between molecules of compound 11. Lately, we reported studies concerning Pz 12, similar in structure to molecule 7 studied here. Singlet oxygen quantum yield values for $12(0.03$ in DMF $[51,53])$ were reported, and are similar to the values obtained for 7 . They indicate that the modification of the linker chain length and the substituents in the periphery of benzene ring had no effect on $\Phi_{\Delta}$, and that it was determined mostly by the central metal ion and the presence of sulfanyl moieties attached to the Pz ring.

\subsubsection{Photostability}

Singlet oxygen formed during irradiation can also self-destructively contribute to the stability of photosensitizer. Two mechanisms of the macrocyclic system decomposition were recognized: (i) photobleaching, which leads to the formation of low-weight, colorless products, and (ii) phototransformation, which can lead to the modification of the macrocycle [54,55]. Pz 7, as well as Pc 3, belong to stable photosensitizers and, after irradiation, decomposed following the photobleaching mechanism. Stable photosensitizers reveal photodecomposition quantum yield $\left(\Phi_{\mathrm{P}}\right)$ values at ca. $10^{-6}$, as categorized by Dilber and co-workers [56]. In this presented study, well-developed peripheries around the macrocyclic cores caused steric hindrances and influenced measured photostabilities in comparison to the reference compound - $\mathrm{ZnPc}$ (Table 2). Interestingly, Pc 3, when dissolved in DMF, revealed $\Phi_{\mathrm{P}}$ values one order of magnitude higher, which might be linked with the predisposition of magnesium(II) macrocycles to the demetallation reaction [57]. On the other hand, the substituents attached to the phthalocyanine ring in 3 stabilize it in comparison to the unsubstituted magnesium(II) phthalocyanine (in DMF $\Phi_{\mathrm{P}}$ equal $52.5 \times 10^{-6}$ vs. $327 \times 10^{-6}$ [43], respectively). The electron-donating groups-sulfanyl bridges-were reported to increase photostability $[55,58]$. The enhancement of photostability could be influenced by the formation of an intracoordination bond between the central magnesium(II) ion and the oxygen atom of the peripheral substituent. We have reported such a phenomenon for alkoxy octa-substituted magnesium(II) phthalocyanine [40]. 

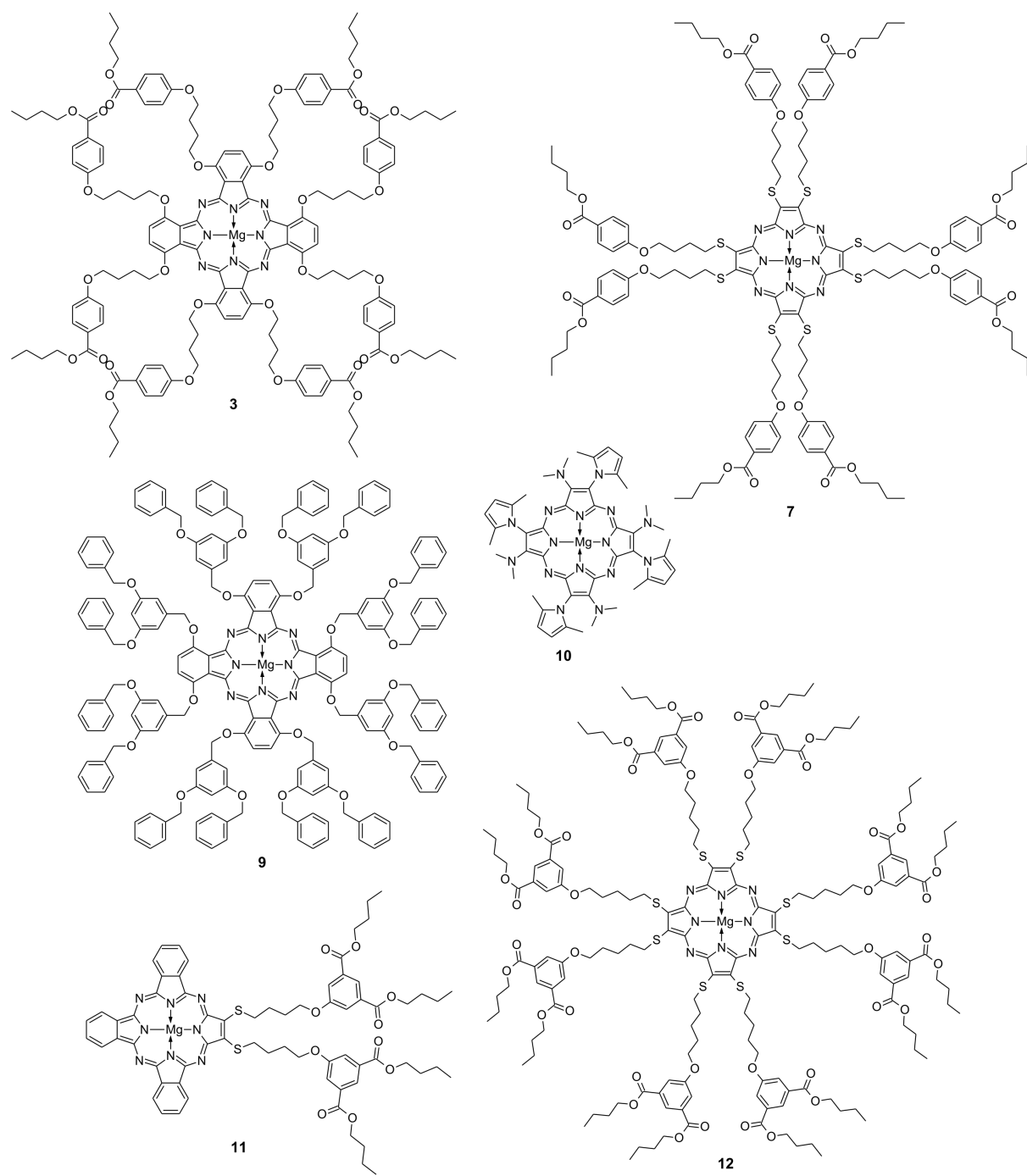

Figure 3. Chemical structures of macrocycles 3, 7 and 9-12.

Table 2. Fluorescence $\left(\Phi_{\mathrm{FL}}\right)$, photodecomposition $\left(\Phi_{\mathrm{P}}\right)$, and singlet oxygen generation $\left(\Phi_{\Delta}\right)$ quantum yields of macrocycles 3 and 7 .

\begin{tabular}{ccccc}
\hline Compound & Solvent & $\boldsymbol{\Phi}_{\mathbf{F L}}$ & $\boldsymbol{\Phi}_{\mathbf{P}}$ & $\boldsymbol{\Phi}_{\boldsymbol{\Delta}}$ \\
\hline \multirow{3}{*}{$\mathbf{3}$} & DMF & 0.007 & $52.50 \times 10^{-6}$ & 0.29 \\
& DMSO & 0.002 & $3.80 \times 10^{-6}$ & 0.13 \\
$\mathbf{7}$ & DMF & - & $3.08 \times 10^{-6}$ & 0.02 \\
& DMSO & - & $2.66 \times 10^{-6}$ & 0.09 \\
$\mathbf{Z n P c}($ reference) & DMF & $0.20[59]$ & $10.2 \times 10^{-6}[60]$ & $0.56[61]$ \\
& DMSO & $0.17[59]$ & $3.5 \times 10^{-6}[60]$ & $0.67[61]$ \\
$\mathbf{9}$ & DMF & $0.17[50]$ & $37.5 \times 10^{-6}[50]$ & $0.13[50]$ \\
& DMSO & $0.04[50]$ & $3.07 \times 10^{-6}[50]$ & $0.11[50]$ \\
$\mathbf{1 0}$ & DMF & $0.046[48]$ & $1.81 \times 10^{-4}[48]$ & $0.14[48]$ \\
& DMSO & $0.012[48]$ & $1.37 \times 10^{-4}[48]$ & $0.14[48]$ \\
$\mathbf{1 1}$ & DMF & $0.008[42]$ & $48.4 \times 10^{-6}[42]$ & $0.05[62]$ \\
& DMSO & $0.002[42]$ & $4.84 \times 10^{-6}[42]$ & $0.08[42]$ \\
$\mathbf{1 2}$ & DMF & - & $6.14 \times 10^{-6}[53]$ & $0.03[51]$ \\
& DMSO & - & - & -
\end{tabular}

ZnPc—zinc(II) phthalocyanine, DMF—N,N-dimethylformamide, DMSO—dimethyl sulfoxide. 


\subsection{Acute Toxicity Assessment}

The obtained macrocycles and titania materials were tested on Aliivibrio fischeri to evaluate their acute toxicity and photocytotoxicity. A. fischeri is a bacterium that emits bioluminescence which is directly correlated to its metabolism and, thus, its viability [63]. The obtained titania materials, as well as $\mathbf{3}$ and $\mathbf{7}$, were studied in water/DMSO mixtures (1\% of DMSO addition). The samples were tested in the dark and upon irradiation with 665 $\mathrm{nm}$ light to assess the difference between irradiated and non-irradiated photosensitizers. Additionally, in order to assess the effect of light and P25 nanoparticles, an experiment with studied bacterium irradiated with light in the absence of the photosensitizer was performed, and a study in which unmodified suspension of P25 was added to the sample containing the bacterium. The results are presented in Figure 4.

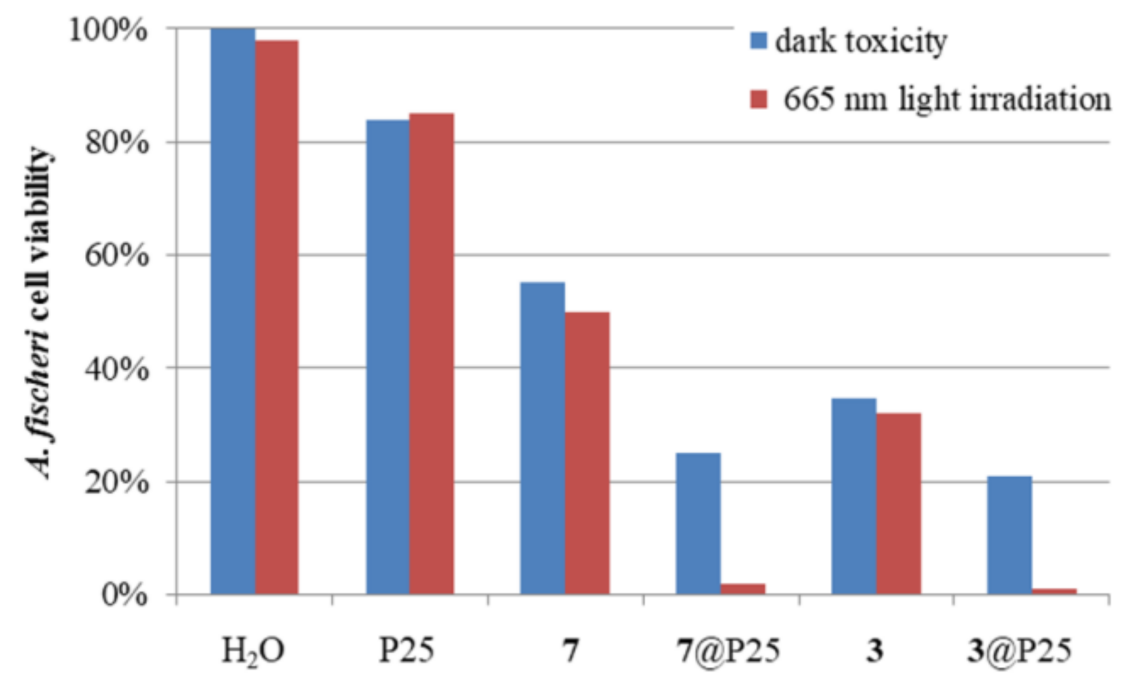

Figure 4. Changes in A. fischeri cell viability after $15 \mathrm{~min}$ of the experiment when incubated with different materials (P25, 3@P25, 7@P25) or compounds $(3,7)$. The addition of water served as the control experiment $\left(\mathrm{H}_{2} \mathrm{O}\right)$.

Initially, the effect of red light on cell viability was measured. It was found that the irradiation had a negligible effect on $A$. fischeri, as cell viability decreased only by $2 \%\left(\mathrm{H}_{2} \mathrm{O}\right.$ in Figure 4). In the case of unmodified P25, the effect was stronger, but still below $20 \%$, which is regarded as non-toxic in a Microtox ${ }^{\circledR}$ test [64]. The compounds 3 and 7 also exhibited significant dark toxicity, which changed only slightly after irradiation. In the case of both materials tested, 3@P 25 and 7@P25, the dark toxicity reached almost $80 \%$, but the effect was the strongest together with irradiation, reaching nearly a $100 \%$ decrease in cell viability. What is more, in the case of the macrocycles deposited on titania, the effect of irradiation was stronger than in the case of macrocycles alone. For Pc derivative 3, cell viability decreased by $3 \%$ upon irradiation, as compared to its dark toxicity, whilst, for $3 @ P 25$, a drop of $20 \%$ was observed.

It seems that the high values measured for the dark toxicity of both nanomaterials and, separately, porphyrinoids, are related to the presence of nipagin moieties present in the periphery of the macrocycles, which are known to exhibit strong antimicrobial properties [65].

\section{Materials and Methods}

\subsection{Materials and Instruments}

All reactions were conducted in oven-dried glassware under an argon atmosphere using Radleys Heat-On ${ }^{\mathrm{TM}}$ heating system. All solvents and reagents were obtained from commercial suppliers and used without further purification, except for dichloromethane, which was distilled before use. All solvents were removed by rotary evaporation at or below $50{ }^{\circ} \mathrm{C}$. Dry flash column chromatography was carried out on Merck silica gel 60, 
particle size 40-63 $\mu \mathrm{m}$; reverse phase Fluka C18 silica gel 90; aluminium oxide 90 active neutral (activity stage I) for column chromatography 0.063-0.200 mm, EMD Millipore. Thinlayer chromatography (TLC) was performed on silica gel Merck Kieselgel $60 \mathrm{~F}_{254}$ plates and Merck Kieselgel RP-18 $60 \mathrm{~F}_{254} \mathrm{~s}$ visualized with UV ( $\lambda_{\max } 254$ or $365 \mathrm{~nm}$ ). All mobile phases and solvent mixtures are given in volume-to-volume $(\mathrm{v} / \mathrm{v})$ ratio, unless otherwise stated. UV-Vis spectra were recorded on Hitachi UV/VIS U-1900 and Shimadzu PC-160 spectrophotometers. ${ }^{1} \mathrm{H}$ and ${ }^{13} \mathrm{C}$ NMR spectra were acquired on an AVANCE II Bruker $400 \mathrm{MHz}$ (9.39 T), AVANCE III Bruker $500 \mathrm{MHz}$ (11.74 T), and AVANCE III Bruker $700 \mathrm{MHz}$ $(16.44 \mathrm{~T})$ spectrometer at $298 \mathrm{~K}$. Chemical shifts $(\delta)$ were reported in parts per million $(\mathrm{ppm})$ and referenced to the residual solvent peak (DMSO- $d_{6}: \delta_{\mathrm{H}}=2.50 \mathrm{ppm}, \delta_{\mathrm{C}}=39.50 \mathrm{ppm}$; pyridine- $\left.d_{5}: \delta_{\mathrm{H}}=8.74,7.58,7.22 \mathrm{ppm}, \delta_{\mathrm{C}}=150.35,135.91,123.87 \mathrm{ppm}\right)$. Coupling constants $(J)$ are quoted in Hertz $(\mathrm{Hz})$ and round up to 0.5 . The abbreviations s, bs, d, t, q, m refer to singlet, broad singlet, doublet, triplet, quadruplet, and multiplet, respectively. ${ }^{1} \mathrm{H}$ and ${ }^{13} \mathrm{C}$ resonances were unambiguously assigned based on ${ }^{1} \mathrm{H}-{ }^{1} \mathrm{H}$ COSY, ${ }^{1} \mathrm{H}-{ }^{13} \mathrm{C}$ HSQC and ${ }^{1} \mathrm{H}-$ ${ }^{13} \mathrm{C}$ HMBC experiments. Mass spectra (MS ES, HRMS ES, MALDI TOF) were carried out by the Wielkopolska Center for Advanced Technologies at Adam Mickiewicz University in Poznan and the Department of Inorganic and Analytical Chemistry at Poznan University of Medical Sciences.

\subsection{Synthesis}

3.2.1. Ethyl 4-(4-bromobutoxy)benzoate (1)

Ethyl 4-hydroxybenzoate $(4.00 \mathrm{~g}, 24.07 \mathrm{mmol}), 1,4$-dibromobutane $(7.10 \mathrm{~mL}, 60.18 \mathrm{mmol})$, and potassium carbonate $(33.27 \mathrm{~g}, 0.24 \mathrm{~mol})$ in $100 \mathrm{~mL}$ of anhydrous DMF were stirred at room temperature for $72 \mathrm{~h}$. Next, the reaction mixture was filtered through Celite and washed with DCM. The filtrate was evaporated and the residue was chromatographed using silica gel and DCM:hexane 1:1 as eluent to give $4.340 \mathrm{~g}$ of colorless liquid, which was identified as 1 (yield 72\%). $\mathrm{R}_{f}$ (DCM:hexane 1:1) 0.38. UV-Vis (DCM): $\lambda_{\max }, \mathrm{nm}(\log \varepsilon) 257$ (4.38). ${ }^{1} \mathrm{H}$ NMR $\left(400 \mathrm{MHz}\right.$, DMSO- $\left.d_{6}\right) \delta 7.90(\mathrm{~d}, J=9.0 \mathrm{~Hz}, 2 \mathrm{H}), 7.03(\mathrm{~d}, J=9.0 \mathrm{~Hz}, 2 \mathrm{H}), 4.25(\mathrm{q}, J=7.0 \mathrm{~Hz}$, $2 \mathrm{H}), 4.07(\mathrm{t}, J=6.5 \mathrm{~Hz}, 2 \mathrm{H}), 3.59(\mathrm{t}, J=6.5 \mathrm{~Hz}, 2 \mathrm{H}), 1.96(\mathrm{~m}, 5 \mathrm{H}), 1.84(\mathrm{~m}, 2 \mathrm{H}), 1.29(\mathrm{t}, J=7.0$ $\mathrm{Hz}, 3 \mathrm{H}) .{ }^{13} \mathrm{C}$ NMR (101 MHz, DMSO- $\left.d_{6}\right) \delta 165.3,162.4,131.1,122.1,114.3,67.0,60.3,34.6$, 29.0, 27.2, 14.2. HRMS (ESI) $\mathrm{m} / z$ found: 301.0435, [M+H] ${ }^{+} \mathrm{C}_{13} \mathrm{H}_{18} \mathrm{BrO}_{3}$ requires 301.0439.

\subsubsection{1,2-Dicyano-3,6-bis [4-(4-ethoxycarbonylphenoxy)butyloxy]benzene (2)}

Compound 1 (4.34 g, $14.41 \mathrm{mmol}$ ), 3,6-dihydroxybenzene-1,2-dicarbonitrile (1.05 g, $6.55 \mathrm{mmol})$, and potassium carbonate $(4.52 \mathrm{~g}, 32.75 \mathrm{mmol})$ were stirred in anhydrous DMF $(45 \mathrm{~mL})$ at room temperature for $20 \mathrm{~h}$. Next, the reaction mixture was poured on ice, the precipitate was filtered, washed with methanol, and recrystallized from ethanol to give $118 \mathrm{mg}$ of 2 as white powder (yield $68 \%) . \mathrm{R}_{f}(\mathrm{DCM}) 0.11$. UV-Vis (DCM): $\lambda_{\max }, \mathrm{nm}(\log \varepsilon)$ 227 (4.47), 252 (4.59), 348 (3.78). ${ }^{1} \mathrm{H}$ NMR (500 MHz, DMSO- $\left.d_{6}\right) \delta 7.89$ (d, $\left.J=8.5,4 \mathrm{H}\right), 7.61$ (s, $2 \mathrm{H}), 7.02(\mathrm{~d}, J=8.5,4 \mathrm{H}), 4.25(\mathrm{~m}, 4 \mathrm{H}), 4.23(\mathrm{~m}, 4 \mathrm{H}), 4.14(\mathrm{~m}, 4 \mathrm{H}), 1.91(\mathrm{~m}, 8 \mathrm{H}), 1.30(\mathrm{t}, J=7.0$, $6 \mathrm{H}) .{ }^{13} \mathrm{C}$ NMR (126 MHz, DMSO-d $\left.d_{6}\right) \delta 165.4,162.4,154.8,131.1,122.0,120.5,114.4,113.5$, 102.8, 69.5, 67.4, 60.3, 25.0, 14.2. HRMS (ESI) $m / z$ found: 601.2541, $[\mathrm{M}+\mathrm{H}]^{+} \mathrm{C}_{34} \mathrm{H}_{37} \mathrm{~N}_{2} \mathrm{O}_{8}$ requires 601.2550 .

3.2.3. Magnesium(II) 1,4,8,11,15,18,22,25-octakis

[4-(4-butoxycarbonylphenoxy)butyloxy]phthalocyanine (3)

Two alternative synthetic routes were elaborated:

i. $\quad$ Using 2 as a precursor

Magnesium turnings ( $4 \mathrm{mg}, 0.133 \mathrm{mmol}$ ) were stirred in refluxing butan-1-ol with a catalytic amount of iodine for $3 \mathrm{~h}$. After cooling, $2(159 \mathrm{mg}, 0.265 \mathrm{mmol})$ was added, and the reaction mixture was stirred under reflux for another $20 \mathrm{~h}$ under an inert gas atmosphere. When the reaction was completed, the mixture was cooled to room temperature and the solvent was evaporated. The residue was washed with a mixture of water and methanol (1:1). After drying in a vacuum, the solid was dissolved in DCM and filtered. The filtrate 
was collected, and the solvent evaporated. The obtained product was purified using column chromatography with silica gel and eluents DCM, DCM/MeOH 50:1, DCM/MeOH 35:1, $\mathrm{DCM} / \mathrm{MeOH}$ 20:1, as well as $\mathrm{C}_{18}$-reversed-phase silica gel and eluents $\mathrm{H}_{2} \mathrm{O} / \mathrm{MeOH}$ 3:1, $\mathrm{DCM} / \mathrm{MeOH}$ 1:3, DCM to give $17 \mathrm{mg}$ of green/yellow film 3 (2.4\% yield).

\section{ii. Using 8 as a precursor}

Magnesium turnings ( $4 \mathrm{mg}, 0.133 \mathrm{mmol}$ ) were stirred in refluxing butan-1-ol with a catalytic amount of iodine for $3 \mathrm{~h}$. After cooling to room temperature, 8 ( $200 \mathrm{mg}, 0.305 \mathrm{mmol})$ was added and the reaction mixture was stirred under reflux for another $20 \mathrm{~h}$ in an inert gas atmosphere. Next, the reaction mixture was cooled to room temperature and the solvent was evaporated. The residue was washed with a mixture of water and methanol (1:1). After drying in a vacuum, the solid was dissolved in DCM and filtered. The filtrate was collected and the solvent evaporated. The obtained product was purified using column chromatography with silica gel and eluents DCM, DCM/MeOH 50:1, DCM/MeOH 35:1, DCM/MeOH 20:1; $\mathrm{C}_{18}$-reversed-phase silica gel and eluents $\mathrm{H}_{2} \mathrm{O} / \mathrm{MeOH}$ 3:1, DCM/MeOH 1:3, DCM to give $68 \mathrm{mg}$ of green/yellow film 3 (34\% yield).

$\mathrm{R}_{f}$ (DCM/methanol 20:1) 0.31. UV-Vis (DCM): $\lambda_{\max }, \mathrm{nm}(\log \varepsilon) 327$ (4.99), 761 (5.06), 807 (5.23). ${ }^{1} \mathrm{H}$ NMR $\left(400 \mathrm{MHz}, \mathrm{Pyr}-d_{5}\right) \delta 8.09(\mathrm{~d}, J=9.0 \mathrm{~Hz}, 16 \mathrm{H}), 7.90(\mathrm{~s}, 8 \mathrm{H}), 7.04(\mathrm{~d}$, $J=9.0 \mathrm{~Hz}, 16 \mathrm{H}), 5.24(\mathrm{t}, J=6.5 \mathrm{~Hz}, 16 \mathrm{H}), 4.29(\mathrm{~d}, J=6.5 \mathrm{~Hz}, 16 \mathrm{H}), 4.26(\mathrm{t}, J=6.5 \mathrm{~Hz}, 16 \mathrm{H})$, $2.52(\mathrm{~m}, 16 \mathrm{H}), 2.31(\mathrm{~m}, 16 \mathrm{H}), 1.60(\mathrm{~m}, 16 \mathrm{H}), 1.34(\mathrm{~m}, 16 \mathrm{H}), 0.85(\mathrm{t}, J=7.5 \mathrm{~Hz}, 24 \mathrm{H}) .{ }^{13} \mathrm{C} \mathrm{NMR}$ $\left(101 \mathrm{MHz}, \mathrm{Pyr}-d_{5}\right) \delta 166.7,163.8,153.8,152.6,132.3,130.4,123.6,119.9,115.1,73.0,68.9$, 65.0, 31.5, 27.3, 27.1, 19.9, 14.3. MS (MALDI) $\mathrm{m} / \mathrm{z}$ found: 2649.2179, [M] ${ }^{+} \mathrm{C}_{152} \mathrm{H}_{176} \mathrm{MgN}_{8} \mathrm{O}_{32}$ requires 2649.2241; 2650.2360, $[\mathrm{M}+\mathrm{H}]^{+} \mathrm{C}_{152} \mathrm{H}_{177} \mathrm{MgN}_{8} \mathrm{O}_{32}$ requires 2650.2319. HPLC purity (see Supplementary Materials).

\subsubsection{2,3-. Bis[4-(4-ethoxycarbonylphenoxy)butylsulfanyl]but-2-enedinitrile (4)}

Compound 1 ( $4.00 \mathrm{~g}, 13.28 \mathrm{mmol})$, dimercaptomaleonitrile sodium salt hydrate (0.99 $\mathrm{g}, 5.31 \mathrm{mmol})$, and potassium carbonate $(7.34 \mathrm{~g}, 53.10 \mathrm{mmol})$ in $45 \mathrm{~mL}$ of anhydrous DMF were stirred at $50{ }^{\circ} \mathrm{C}$ for $20 \mathrm{~h}$. Then, the reaction mixture was filtered through Celite and washed with DCM. The filtrate was evaporated and the crude residue was chromatographed on a silica gel (DCM, next DCM:MeOH 100:1) to give $1.532 \mathrm{~g}$ of a dense yellow liquid 4 (49\% yield). $\mathrm{R}_{f}(\mathrm{DCM} / \mathrm{MeOH} 50: 1)$ 0.58. UV-Vis (DCM): $\lambda_{\max }, \mathrm{nm}$ (log ع) $343(3.86), 258(4.51) .{ }^{1} \mathrm{H}$ NMR $\left(500 \mathrm{MHz}, \mathrm{DMSO}-d_{6}\right) \delta 7.89(\mathrm{~d}, J=9.0 \mathrm{~Hz}, 4 \mathrm{H}), 6.99(\mathrm{~d}$, $J=9.0 \mathrm{~Hz}, 4 \mathrm{H}), 4.26(\mathrm{q}, J=7.0 \mathrm{~Hz}, 4 \mathrm{H}), 4.05(\mathrm{t}, J=5.5 \mathrm{~Hz}, 4 \mathrm{H}), 3.23(\mathrm{t}, J=6.5 \mathrm{~Hz}, 4 \mathrm{H}), 1.82$ $(\mathrm{m}, 8 \mathrm{H}), 1.29(\mathrm{t}, J=7.0 \mathrm{~Hz}, 6 \mathrm{H}) .{ }^{13} \mathrm{C}$ NMR $\left(126 \mathrm{MHz}, \mathrm{DMSO}-d_{6}\right) \delta 165.3,162.3,131.1,122.0$, $121.1,114.3,112.3,67.0,60.2,34.1,27.1,26.1,14.1$. HRMS (ESI) $\mathrm{m} / z$ found: $583.1927,[\mathrm{M}+\mathrm{H}]^{+}$ $\mathrm{C}_{30} \mathrm{H}_{35} \mathrm{~N}_{2} \mathrm{O}_{6} \mathrm{~S}_{2}$ requires 583.1937.

\subsubsection{Butyl 4-(4-bromobutoxy)benzoate (5)}

Butyl 4-hydroxybenzoate $(8.0 \mathrm{~g}, 41 \mathrm{mmol})$ and 1,4-dibromobutane $(13.34 \mathrm{~g}, 7.26 \mathrm{~mL}$, $62 \mathrm{mmol})$ were stirred with $\mathrm{K}_{2} \mathrm{CO}_{3}(28.5 \mathrm{~g}, 206 \mathrm{mmol})$ in $100 \mathrm{~mL} \mathrm{DMF}$ at room temperature for $24 \mathrm{~h}$. After that, solvents were evaporated and an oily residue was dissolved in DCM and hexane 1:1 mixture. The solution was filtered and the filtrate was evaporated under reduced pressure. Next, the residue was dissolved in DCM and washed with $10 \% \mathrm{NaOH}$ and water. The collected organic phases were dried with $\mathrm{MgSO}_{4}$, evaporated to give a liquid residue, and chromatographed (silica gel, eluents: hexane, DCM/hexane 1:1) to yield $3.42 \mathrm{~g}$ of 5 (25\% yield). $\mathrm{R}_{f}$ (DCM/hexane 1:1) 0.21 . UV-Vis (DCM): $\lambda_{\max }, \mathrm{nm}$ (log ع) 255 (4.69). ${ }^{1} \mathrm{H}$ NMR (500 MHz, Pyr- $\left.d_{5}\right) \delta 8.18(\mathrm{~m}, 2 \mathrm{H}, \mathrm{ArH}, \mathrm{C} 2(\mathrm{C} 6)), 7.16(\mathrm{~m}, 2 \mathrm{H}, \mathrm{ArH}$, $\mathrm{C} 3(\mathrm{C} 5)), 5.51\left(\mathrm{t}, J=7.5,2 \mathrm{H}, \mathrm{BrCH}_{2}\right), 4.33\left(\mathrm{t}, J=6.5,2 \mathrm{H}, \mathrm{COOCH}_{2}\right), 4.17(\mathrm{t}, J=6.5,2 \mathrm{H}$, $\left.\mathrm{BrCH}_{2} \mathrm{CH}_{2} \mathrm{CH}_{2} \mathrm{CH}_{2}\right), 2.41\left(\mathrm{~m}, 2 \mathrm{H}, \mathrm{BrCH}_{2} \mathrm{CH}_{2}\right), 2.04\left(\mathrm{~m}, 2 \mathrm{H}, \mathrm{BrCH}_{2} \mathrm{CH}_{2} \mathrm{CH}_{2}\right), 1.64(\mathrm{~m}, 2 \mathrm{H}$, $\left.\mathrm{CH}_{2} \mathrm{CH}_{2} \mathrm{CH}_{3}\right), 1.35\left(\mathrm{~m}, 2 \mathrm{H}, \mathrm{CH}_{2} \mathrm{CH}_{3}\right), 0.86\left(\mathrm{t}, J=7.5,3 \mathrm{H}, \mathrm{CH}_{3}\right) .{ }^{13} \mathrm{C} \overline{\mathrm{NMR}}(126 \mathrm{MHz}$, Pyr- $\left.d_{5}\right) \delta 166.8,163.6,132.4,123.8,115.4,68.4,65.1,61.3,31.5,29.4,26.5,20.0,14.3$. MS ESI $\mathrm{m} / \mathrm{z}$ : found 351.0575, calculated for $\mathrm{C}_{15} \mathrm{H}_{21} \mathrm{BrO}_{3} \mathrm{Na}[\mathrm{M}+\mathrm{Na}]^{+} 351.0572$. 
An additional byproduct was formed in this reaction, which readily precipitated upon addition of hexane to dichloromethane solution of the oily residue after DMF evaporation. This byproduct was obtained in the form of white powder in the amount of $3.9 \mathrm{~g}$, and was identified as 1,4-bis(4-butylcarbonylphenyloxy)butane 5D (43\% yield).

$\mathrm{R}_{f}\left(\mathrm{DCM} /\right.$ hexane 1:1) 0.05. UV-Vis (DCM): $\lambda_{\max }, \mathrm{nm}(\log \varepsilon) 256$ (4.40). ${ }^{1} \mathrm{H}$ NMR $(400 \mathrm{MHz}$, DMSO) $\delta 7.85(\mathrm{~m}, 4 \mathrm{H}, \mathrm{ArH} \mathrm{C2}(\mathrm{C} 6)), 7.00(\mathrm{~m}, 4 \mathrm{H}, \mathrm{ArH} \mathrm{C} 3(\mathrm{C} 5)), 4.20\left(\mathrm{t}, J=6.5,4 \mathrm{H}, \mathrm{COOCH}_{2}\right)$, 4.09 (bs, $\left.4 \mathrm{H}, \mathrm{ArOCH}_{2}\right), 1.87$ (bs, $\left.4 \mathrm{H}, \mathrm{ArOCH}_{2} \mathrm{CH}_{2}\right), 1.64\left(\mathrm{~m}, 4 \mathrm{H}, \mathrm{COOCH}_{2} \mathrm{CH}_{2} \mathrm{CH}_{2}\right), 1.37(\mathrm{~m}$,

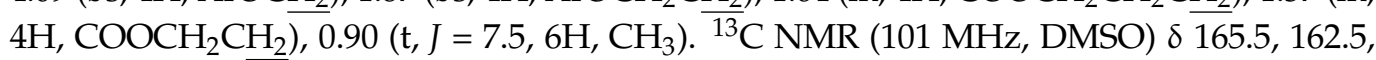
$131.2,122.0,114.5,67.5,64.0,30.3,25.2,18.8,13.6$. MS ESI $m / z$ : found 465.2259 , calculated for $\mathrm{C}_{26} \mathrm{H}_{34} \mathrm{O}_{6} \mathrm{Na}[\mathrm{M}+\mathrm{Na}]^{+} 465.2253$.

\subsubsection{2,3-Bis[4-(4-butoxycarbonylphenoxy)butylsulfanyl]but-2-enedinitrile (6)}

Compound 5 ( $3.42 \mathrm{~g}, 10.38 \mathrm{mmol})$, dimercaptomaleonitrile sodium salt hydrate $(0.77 \mathrm{~g}$, $4.15 \mathrm{mmol}$ ), and potassium carbonate $(5.74 \mathrm{~g}, 41.53 \mathrm{mmol})$ in $45 \mathrm{~mL}$ of anhydrous DMF were stirred at $50{ }^{\circ} \mathrm{C}$ for $20 \mathrm{~h}$. Next, the reaction mixture was filtered through Celite and washed with DCM. The filtrate was evaporated and the residue was chromatographed (using silica gel and eluents: DCM, DCM/hexane 1:1, DCM/MeOH 100:1, DCM/MeOH 50:1) to give $1.24 \mathrm{~g}$ of yellow liquid 6 (yield $47 \%$ ).

$\mathrm{R}_{f}(\mathrm{DCM})=0.12 . \mathrm{UV}-\mathrm{Vis}(\mathrm{DCM}): \lambda_{\max }, \mathrm{nm}(\log \varepsilon): 405$ (4.87), $290(5.21) .{ }^{1} \mathrm{H}$ NMR $\left(500 \mathrm{MHz}, \mathrm{DMSO}-d_{6}\right) \delta 7.88(\mathrm{~m}, 4 \mathrm{H}, \mathrm{ArH} \mathrm{C} 3(\mathrm{C} 5)), 7.00(\mathrm{~m}, 4 \mathrm{H}, \mathrm{ArH} \mathrm{C} 2(\mathrm{C} 6)), 4.22(\mathrm{t}$, $\left.J=6.5,4 \mathrm{H}, \mathrm{COOCH}_{2}\right), 4.07\left(\mathrm{t}, J=5.5,4 \mathrm{H}, \mathrm{ArOCH}_{2}\right), 3.25\left(\mathrm{t}, J=6.5,4 \mathrm{H}, \mathrm{SCH}_{2}\right), 1.83(\mathrm{~m}$, $\left.8 \mathrm{H}, \mathrm{SCH}_{2} \mathrm{CH}_{2} \mathrm{CH}_{2}\right), 1.67\left(\mathrm{~m}, 4 \mathrm{H}, \mathrm{COOCH}_{2} \mathrm{CH}_{2}\right), \overline{1.40}\left(\mathrm{~m}, 4 \mathrm{H}, \mathrm{COOCH}_{2} \mathrm{CH}_{2} \overline{\mathrm{CH}_{2}}\right), 0.92(\mathrm{t}$, $\left.J=7.5,6 \mathrm{H}, \overline{\mathrm{CH}}_{3}\right) .{ }^{13} \mathrm{C} \mathrm{NMR}\left(126 \mathrm{MHz}, \mathrm{DMSO}-d_{6}\right) \delta 165.4,162.3,131.0,122.0,121.2,114.3$, 112.4, 67.1, 63.9, 34.1, 30.3, 27.1, 26.1, 18.7, 13.6. HRMS ESI $\mathrm{m} / \mathrm{z}$ found: 661.2381 , calculated for $[\mathrm{M}+\mathrm{Na}]^{+} \mathrm{C}_{34} \mathrm{H}_{42} \mathrm{~N}_{2} \mathrm{O}_{6} \mathrm{~S}_{2} \mathrm{Na} 661.2382$.

\subsubsection{2,3,7,8,12,13,17,18-Octakis[4-(4-butoxycarbonylphenoxy)butylsulfanyl]} porphyrazinato magnesium(II) (7)

Magnesium turnings ( $6 \mathrm{mg}, 0.235 \mathrm{mmol}$ ) were stirred in refluxing butan-1-ol with a catalytic amount of iodine for $3 \mathrm{~h}$. After cooling, $6(300 \mathrm{mg}, 0.470 \mathrm{mmol})$ was added and the reaction mixture was stirred under reflux for another $20 \mathrm{~h}$ in an inert gas atmosphere. After cooling to room temperature, the solvent was evaporated. The solid residue was purified by column chromatography using silica gel and eluents DCM, DCM/MeOH 50:1; $\mathrm{C}_{18}$ reversed-phase silica gel and eluents $\mathrm{H}_{2} \mathrm{O} / \mathrm{MeOH}$ 100:1, $\mathrm{H}_{2} \mathrm{O} / \mathrm{MeOH} 35: 1, \mathrm{H}_{2} \mathrm{O} / \mathrm{MeOH}$ 3:1, DCM/MeOH 1:3, DCM to give $98 \mathrm{mg}$ of deep blue film 7 (32\% yield).

$\mathrm{R}_{f}$ (DCM/MeOH 50:1) 0.12. UV-Vis (DCM): $\lambda_{\max }, \mathrm{nm}(\log \varepsilon): 672$ (5.37), 376 (5.34), 255 (5.70). ${ }^{1} \mathrm{H}$ NMR $\left(500 \mathrm{MHz}, \mathrm{DMSO}-d_{6}\right) \delta 7.87(\mathrm{~m}, 16 \mathrm{H}, \mathrm{ArH} \mathrm{C} 3(\mathrm{C} 5)), 6.99(\mathrm{~m}, 16 \mathrm{H}, \mathrm{ArH}$ $\mathrm{C} 2(\mathrm{C} 6)), 4.21\left(\mathrm{t}, J=6.5,16 \mathrm{H}, \mathrm{COOCH}_{2}\right), 4.06\left(\mathrm{t}, J=5.5,16 \mathrm{H}, \mathrm{ArOCH}_{2}\right), 3.24(\mathrm{t}, J=6.5,16 \mathrm{H}$, $\left.\mathrm{SCH}_{2} \mathrm{CH}_{2} \mathrm{CH}_{2}\right), 1.83\left(\mathrm{~m}, 32 \mathrm{H}, \mathrm{SCH}_{2} \overline{\mathrm{CH}}_{2} \mathrm{CH}_{2}\right), 1.66\left(\mathrm{~m}, 16 \mathrm{H}, \mathrm{COOCH}_{2} \mathrm{CH}_{2}\right), 1.39(\mathrm{~m}, 16 \mathrm{H}$, $\left.\mathrm{COOCH}_{2} \mathrm{CH}_{2} \mathrm{CH}_{2}\right), 0.92\left(\mathrm{t}, J=7.5,2 \overline{\mathrm{H}}, \overline{\mathrm{CH}}_{3}\right) .{ }^{13} \mathrm{C} \mathrm{NMR}\left(126 \mathrm{MHz}, \overline{\mathrm{DMSO}}-d_{6}\right) \delta 165.4$, 162.3, 131.0, 122.0, 121.2, 114.3, 112.4, 67.1, 63.9, 34.1, 30.3, 27.1, 26.1, 18.7, 13.6. HRMS ESI $\mathrm{m} / \mathrm{z}$ found: 2465.7714 , calculated for $[\mathrm{M}+\mathrm{H}]^{+} \mathrm{C}_{128} \mathrm{H}_{153} \mathrm{MgN}_{8} \mathrm{O}_{24} \mathrm{~S}_{8}$ 2465.8614. HPLC purity (see Supplementary Materials).

\subsubsection{1,2-Dicyano-3,6-bis[4-(4-butoxycarbonylphenoxy)butyloxy]benzene (8)}

3,6-Dihydroxybenzene-1,2-dicarbonitrile ( $389 \mathrm{mg}, 2.43 \mathrm{mmol})$ and $5(2.00 \mathrm{~g}, 6.07 \mathrm{mmol})$ were stirred with $\mathrm{K}_{2} \mathrm{CO}_{3}(1.68 \mathrm{~g}, 12.15 \mathrm{mmol})$ in $40 \mathrm{~mL}$ DMF at room temperature for $72 \mathrm{~h}$. After that, the reaction mixture was poured on ice $(50 \mathrm{~mL})$ and filtered. The solid was washed with water and methanol to yield $1.21 \mathrm{~g}$ of white solid 8 (yield $76 \%$ ).

$\mathrm{R}_{f}$ (DCM/MeOH 50:1) 0.64. UV-Vis (DCM): $\lambda_{\max }, \mathrm{nm}(\log \varepsilon): 356$ (3.87), 251 (4.74), 228 (4.63). ${ }^{1} \mathrm{H} \mathrm{NMR}\left(700 \mathrm{MHz}, \mathrm{DMSO}-d_{6}\right) \delta 7.85(\mathrm{~m}, 4 \mathrm{H}, \mathrm{ArH} \mathrm{C}(\mathrm{C} 5)), 7.59$ (s, $2 \mathrm{H}$, hydroquinone $\mathrm{ArH}), 7.00(\mathrm{~m}, 4 \mathrm{H}, \mathrm{ArH} \mathrm{C}(\mathrm{C} 6)), 4.20\left(\mathrm{~m}, 8 \mathrm{H}, \mathrm{COOCH}_{2}\right.$ and $\left.\mathrm{OCH}_{2} \mathrm{CH}_{2} \mathrm{CH}_{2} \mathrm{CH}_{2}\right), 4.12(\mathrm{~s}$, $\left.4 \mathrm{H}, \mathrm{OCH}_{2} \mathrm{CH}_{2} \mathrm{CH}_{2} \mathrm{CH}_{2}\right), 1.89$ (s, 8H, OCH $\left.\left.\mathrm{CH}_{2} \mathrm{CH}_{2} \mathrm{CH}_{2}\right), 1.65 \overline{(\mathrm{m}}, 4 \mathrm{H}, \mathrm{COOCH}_{2} \mathrm{CH}_{2}\right)$, $1.38\left(\mathrm{~m}, 4 \mathrm{H}, \mathrm{CH}_{2} \mathrm{CH}_{3}\right), 0.90\left(\mathrm{t}, J=7.5,6 \mathrm{H}, \mathrm{CH}_{3}\right) .{ }^{13} \mathrm{C} \mathrm{NMR}\left(176 \mathrm{MHz}, \mathrm{DMSO}-d_{6}\right) \delta 165.4$, 
162.4, 154.8, 131.2, 122.0, 120.5, 114.4, 113.6, 102.8, 69.4, 67.4, 64.0, 30.3, 25.0, 18.8, 13.6. MS ESI $m / z$ : found 679.2988, calculated for $\mathrm{C}_{38} \mathrm{H}_{44} \mathrm{~N}_{2} \mathrm{O}_{8} \mathrm{Na}[\mathrm{M}+\mathrm{Na}]^{+} 679.2995$.

\subsection{Photochemical Studies}

Singlet oxygen formation quantum yields in solution were measured according to the procedure described before [48,59,60,66]. 1,3-Diphenylisobenzofuran (DPBF) was used as a singlet oxygen chemical quencher, whereas $\mathrm{ZnPc}$ was applied as a reference $\Phi_{\Delta}$ generator. The photostability of studied macrocycles in solution was also evaluated and determined using the photodecomposition quantum yields $\left(\Phi_{\mathrm{P}}\right)[60,66-68]$. Fluorescence quantum yields were determined with the earlier described indirect method, with the reference compound-ZnPc [48,59,61,69].

\subsection{Deposition of 3 and 7 on $\mathrm{TiO}_{2}$ P25 Nanoparticles}

Obtained macrocyclic compounds were deposited on P25 Aeroxide ${ }^{\circledR}$ (Merck KGaA, Darmstadt, Germany) $\mathrm{TiO}_{2}$ nanoparticles using the chemical deposition method [70]. Briefly, to a dispersion of P25 nanoparticles (sized $21 \mathrm{~nm}$ ) in dichloromethane (100 mg in $20 \mathrm{~mL})$, a solution of either 3 or $7(10 \mathrm{mg})$ in dichloromethane $(5 \mathrm{~mL})$ was added, and the reaction mixture was stirred for $16 \mathrm{~h}$. Next, the solvent was evaporated under reduced pressure and the material was dried in air. The ratio of the macrocycle to the P25 was assessed to be 1:10 $(w / w)$.

The nanoparticles were characterized by particle size measurements. The nanoparticle size distribution was analyzed using Malvern Panalytical NanoSight LM10 instrument (sCMOS camera, $405 \mathrm{~nm}$ laser; Malvern, United Kingdom) using NTA (Nanoparticle Tracking Analysis) 3.2 Dev Build 3.2.16 software (Malvern, United Kingdom). Before the measurements, the dispersions of the materials were diluted with water to achieve the operating range of nanoparticle concentration. The temperature of the sample chamber was set and maintained at $25.0 \pm 0.1^{\circ} \mathrm{C}$, and the syringe pump infusion rate was set to 200 .

\subsection{Acute Toxicity Assessment}

The toxicity of materials was assessed using the Microtox ${ }^{\circledR}$ (Modern Water, Cambridge, UK) acute toxicity test [63]. The test was modified to assess compounds' phototoxic potential, following the previously presented methodology [18]. Briefly, two sets of experiments were conducted: dark toxicity and light toxicity tests. An additional red-light diode $\left(\lambda_{\max }=665 \mathrm{~nm}\right)$ was mounted above the Microtox ${ }^{\circledR}$ M500 (Modern Water, Cambridge, UK) cuvette incubator to study compounds and materials' photocytotoxicities. The red-light diode was used to irradiate the prepared samples upon combining with Aliivibrio fischeri bacteria. The light intensity was set to $7.0 \mathrm{~mW} / \mathrm{cm}^{2}$ at the samples' surface (as measured with Radiometer RD 0.2/2 with TD probe, Optel). Cell viability was calculated using Modern Water MicrotoxOmni 4.2 software (Modern Water, London, UK), according to bioluminescence emitted by the bacteria measured with Microtox ${ }^{\circledR}$ M500. Macrocycles 3 and 7 were solubilized with DMSO ( $1 \% \mathrm{v} / \mathrm{v})$. Distilled water was used as the solvent for all the materials. The concentrations of the porphyrinoids added to $A$. fischeri cultures were $10^{-4} \mathrm{~mol} / \mathrm{dm}^{3}$.

\section{Conclusions}

Two new macrocycles were synthesized, namely magnesium(II) 1,4,8,11,15,18,22,25octakis[4-(4-butoxycarbonylphenoxy)butyloxy]phthalocyanine (3) and 2,3,7,8,12,13,17,18octakis[4-(4-butoxycarbonylphenoxy)butylsulfanyl]porphyrazinato magnesium(II) (7). The synthesis of both compounds was optimized by changing the starting material from ethyl 4-hydroxybenzoate to 1-butyl 4-hydroxybenzoate, which resulted in higher yields of Pc 3 synthesis and allowed us to synthesize and isolate Pz 7. Both macrocycles were characterized using spectral methods-NMR $\left({ }^{1} \mathrm{H}\right.$ NMR, ${ }^{13} \mathrm{C}$ NMR, ${ }^{1} \mathrm{H}-{ }^{1} \mathrm{H}$ COSY, ${ }^{1} \mathrm{H}_{-}{ }^{13} \mathrm{C}$ HSQC, $\left.{ }^{1} \mathrm{H}_{-}{ }^{13} \mathrm{C} \mathrm{HMBC}\right), \mathrm{UV}-\mathrm{Vis}$ spectroscopy, and mass spectrometry. Each macrocycle revealed high photostability $\left(\Phi_{\mathrm{P}} \sim 10^{-6}\right)$. However, when it comes to emission properties, 
only Pc 3 revealed fluorescence, whereas Pz 7 did not exhibit emission. In addition, Pc 3 also exhibited much higher quantum yields of singlet oxygen generation, which reached 0.29 in DMF and 0.13 in DMSO, in comparison to Pz 7, with 0.02 in DMF and 0.09 in DMSO.

After depositing 3 and 7 on P25 titania nanoparticles, the obtained nanoparticles 3@P25 and 7@P25 were studied in a Microtox ${ }^{\circledR}$ screening test. In the case of both materials tested, dark toxicity reached almost $80 \%$, but the effect was the strongest together with irradiation, reaching nearly a 100\% decrease in cell viability. It was found that 3@P25 nanoparticles, in comparison to 3 alone, revealed a higher cytotoxicity/photocytotoxicity. Further potential of this material as a photocatalyst for decontamination of microbially polluted water could be considered.

Supplementary Materials: The following are available online, Table S1: ${ }^{1} \mathrm{H}$ and ${ }^{13} \mathrm{C}$ NMR data obtained for 1 including key correlations determined from ${ }^{1} \mathrm{H}_{-}{ }^{1} \mathrm{H}$ COSY, ${ }^{1} \mathrm{H}_{-}{ }^{13} \mathrm{C}$ HSQC and ${ }^{1} \mathrm{H}_{-}{ }^{13} \mathrm{C}$ HMBC spectra. Figure S1: ${ }^{1} \mathrm{H}$ and $\left({ }^{13} \mathrm{C}\right)$ chemical shift values [ppm] and key correlations observed in NMR spectra of 1 . Bold lines: ${ }^{1} \mathrm{H}_{-}{ }^{1} \mathrm{H}$ COSY; Arrows: ${ }^{1} \mathrm{H}_{-}{ }^{13} \mathrm{C}$ HMBC. Figure S2: ${ }^{1} \mathrm{H}$ NMR spectrum of $1\left(400 \mathrm{MHz}, \mathrm{DMSO}-d_{6}, 298 \mathrm{~K}\right)$. The symbols * and $\sim$ indicate DMSO- $d_{6}$ and water residual peaks, respectively. Figure S3: ${ }^{13} \mathrm{C}$ NMR spectrum recorded for 1 (101 MHz, DMSO- $\left.d_{6}, 298 \mathrm{~K}\right)$. The symbol * indicates DMSO- $d_{6}$ residual peak. Table S2: ${ }^{1} \mathrm{H}$ and ${ }^{13} \mathrm{C}$ NMR data obtained for 2 including key correlations determined from ${ }^{1} \mathrm{H}_{-}{ }^{1} \mathrm{H}$ COSY, ${ }^{1} \mathrm{H}_{-}{ }^{13} \mathrm{C}$ HSQC and ${ }^{1} \mathrm{H}_{-}{ }^{13} \mathrm{C}$ HMBC spectra. Figure S4: ${ }^{1} \mathrm{H}$ and $\left({ }^{13} \mathrm{C}\right)$ chemical shift values [ppm] and key correlations observed in NMR spectra of 2 . Bold lines: ${ }^{1} \mathrm{H}-{ }^{1} \mathrm{H}$ COSY; Arrows: ${ }^{1} \mathrm{H}-{ }^{13} \mathrm{C}$ HMBC. Figure S5: ${ }^{1} \mathrm{H}$ NMR spectrum of $2\left(500 \mathrm{MHz}, \mathrm{DMSO}-d_{6}\right.$, $298 \mathrm{~K})$. The symbols * and $\sim$ indicate DMSO- $d_{6}$ and water residual peaks, respectively. Figure S6: ${ }^{13} \mathrm{C}$ NMR spectrum recorded for $2\left(126 \mathrm{MHz}, \mathrm{DMSO}-d_{6}, 298 \mathrm{~K}\right)$. The symbol * indicates DMSO- $d_{6}$ residual peak. Table S3: ${ }^{1} \mathrm{H}$ and ${ }^{13} \mathrm{C}$ NMR data obtained for 3 including key correlations determined from ${ }^{1} \mathrm{H}_{-}{ }^{1} \mathrm{H}$ COSY, ${ }^{1} \mathrm{H}_{-}{ }^{13} \mathrm{C}$ HSQC and ${ }^{1} \mathrm{H}_{-}{ }^{13} \mathrm{C}$ HMBC spectra. Figure S7: ${ }^{1} \mathrm{H}$ and $\left({ }^{13} \mathrm{C}\right)$ chemical shift values [ppm] and key correlations observed in NMR spectra of 3 . Bold lines: ${ }^{1} \mathrm{H}-{ }^{1} \mathrm{H}$ COSY; Arrows: ${ }^{1} \mathrm{H}_{-}{ }^{13} \mathrm{C}$ HMBC. Figure S8: ${ }^{1} \mathrm{H}$ NMR spectrum of $3\left(500 \mathrm{MHz}\right.$, pyridine- $\left.d_{5}, 298 \mathrm{~K}\right)$. The symbols \# and $\sim$ indicate pyridine- $d_{5}$ and water residual peaks, respectively. Figure S9: ${ }^{13} \mathrm{C}$ NMR spectrum recorded for 3 (126 MHz, pyridine- $\left.d_{5}, 298 \mathrm{~K}\right)$. The symbols \# indicate pyridine- $d_{5}$ residual peaks. Table S4: ${ }^{1} \mathrm{H}$ and ${ }^{13} \mathrm{C}$ NMR data obtained for 4 including key correlations determined from ${ }^{1} \mathrm{H}-{ }^{1} \mathrm{H}$ COSY, ${ }^{1} \mathrm{H}_{-}{ }^{13} \mathrm{C}$ HSQC and ${ }^{1} \mathrm{H}_{-}{ }^{13} \mathrm{C}$ HMBC spectra. Figure S10: ${ }^{1} \mathrm{H}$ and $\left({ }^{13} \mathrm{C}\right)$ chemical shift values [ppm] and key correlations observed in NMR spectra of 4 . Bold lines: ${ }^{1} \mathrm{H}_{-}{ }^{1} \mathrm{H}$ COSY; Arrows: ${ }^{1} \mathrm{H}_{-}{ }^{13} \mathrm{C}$ HMBC. Figure S11: ${ }^{1} \mathrm{H}$ NMR spectrum of $4\left(400 \mathrm{MHz}, \mathrm{DMSO}-d_{6}, 298 \mathrm{~K}\right)$. The symbols * and $\sim$ indicate DMSO- $d_{6}$ and water residual peaks, respectively. Figure S12: ${ }^{13} \mathrm{C}$ NMR spectrum recorded for 4 $\left(101 \mathrm{MHz}, \mathrm{DMSO}-d_{6}, 298 \mathrm{~K}\right)$. The symbol * indicates DMSO- $d_{6}$ residual peak. Figure S13. Presumed structure of 4 macrocyclization product. Table S5: ${ }^{1} \mathrm{H}$ and ${ }^{13} \mathrm{C}$ NMR data obtained for the product of 4 macrocyclization including key correlations determined from ${ }^{1} \mathrm{H}_{-}{ }^{1} \mathrm{H}$ COSY, ${ }^{1} \mathrm{H}_{-}{ }^{13} \mathrm{C}$ HSQC and ${ }^{1} \mathrm{H}-{ }^{13} \mathrm{C}$ HMBC spectra. Figure S14: ${ }^{1} \mathrm{H}$ and $\left({ }^{13} \mathrm{C}\right)$ chemical shift values [ppm] and key correlations observed in NMR spectra of the product of 4 macrocyclization. Bold lines: ${ }^{1} \mathrm{H}-{ }^{1} \mathrm{H}$ COSY; Arrows: ${ }^{1} \mathrm{H}_{-}{ }^{13} \mathrm{C}$ HMBC. Figure S15: ${ }^{1} \mathrm{H}$ NMR spectrum of the product of 4 macrocyclization $(500 \mathrm{MHz}$, pyridine- $\left.d_{5}, 298 \mathrm{~K}\right)$. The symbols \# and $\sim$ indicate pyridine- $d_{5}$ and water residual peaks, respectively. Figure S16: ${ }^{13} \mathrm{C}$ NMR spectrum recorded for the product of 4 macrocyclization $\left(126 \mathrm{MHz}\right.$, pyridine- $d_{5}$, $298 \mathrm{~K})$. The symbol \# indicates pyridine- $d_{5}$ residual peaks. Table S6: ${ }^{1} \mathrm{H}$ and ${ }^{13} \mathrm{C}$ NMR data obtained for 5 including key correlations determined from ${ }^{1} \mathrm{H}-{ }^{1} \mathrm{H}$ COSY, ${ }^{1} \mathrm{H}_{-}{ }^{13} \mathrm{C}$ HSQC and ${ }^{1} \mathrm{H}-{ }^{13} \mathrm{C} \mathrm{HMBC}$ spectra. Figure S17: ${ }^{1} \mathrm{H}$ and $\left({ }^{13} \mathrm{C}\right)$ chemical shift values [ppm] and key correlations observed in NMR spectra of 5. Bold lines: ${ }^{1} \mathrm{H}-{ }^{1} \mathrm{H}$ COSY; Arrows: ${ }^{1} \mathrm{H}-{ }^{13} \mathrm{C}$ HMBC. Figure S18: ${ }^{1} \mathrm{H}$ NMR spectrum of $5\left(500 \mathrm{MHz}\right.$, pyridine- $\left.d_{5}, 298 \mathrm{~K}\right)$. The symbols * and $\sim$ indicate pyridine- $d_{5}$ and water residual peaks, respectively. Figure S19: ${ }^{13} \mathrm{C}$ NMR spectrum recorded for 5 (126 MHz, pyridine- $d_{5}, 298 \mathrm{~K}$ ). The symbol * indicates pyridine- $d_{5}$ residual peak. Table S7: ${ }^{1} \mathrm{H}$ and ${ }^{13} \mathrm{C}$ NMR data obtained for 5D including key correlations determined from ${ }^{1} \mathrm{H}-{ }^{1} \mathrm{H}$ COSY, ${ }^{1} \mathrm{H}_{-}{ }^{13} \mathrm{C}$ HSQC and ${ }^{1} \mathrm{H}-{ }^{13} \mathrm{C}$ HMBC spectra. Figure S20: ${ }^{1} \mathrm{H}$ and $\left({ }^{13} \mathrm{C}\right)$ chemical shift values [ppm] and key correlations observed in NMR spectra of 5D. Bold lines: ${ }^{1} \mathrm{H}-{ }^{1} \mathrm{H}$ COSY; Arrows: ${ }^{1} \mathrm{H}-{ }^{13} \mathrm{C}$ HMBC. Figure S21: ${ }^{1} \mathrm{H}$ NMR spectrum of $5 \mathrm{D}\left(400 \mathrm{MHz}, \mathrm{DMSO}-d_{6}, 298 \mathrm{~K}\right)$. The symbols \# and $\sim$ indicate DMSO- $d_{6}$ and water residual peaks, respectively. Figure S22: ${ }^{13} \mathrm{C}$ NMR spectrum recorded for $5 \mathrm{D}\left(101 \mathrm{MHz}\right.$, DMSO- $\left.d_{6}, 298 \mathrm{~K}\right)$. The symbol \# indicates DMSO- $d_{6}$ residual peak. Table S8: ${ }^{1} \mathrm{H}$ and ${ }^{13} \mathrm{C}$ NMR data obtained for 6 including key correlations determined from ${ }^{1} \mathrm{H}_{-}{ }^{1} \mathrm{H}$ COSY, ${ }^{1} \mathrm{H}^{13} \mathrm{C}$ HSQC and ${ }^{1} \mathrm{H}_{-}{ }^{13} \mathrm{C}$ HMBC spectra. Figure 
S23: ${ }^{1} \mathrm{H}$ and $\left({ }^{13} \mathrm{C}\right)$ chemical shift values [ppm] and key correlations observed in NMR spectra of 6 . Bold lines: ${ }^{1} \mathrm{H}_{-}{ }^{1} \mathrm{H}$ COSY; Arrows: ${ }^{1} \mathrm{H}_{-}{ }^{13} \mathrm{C}$ HMBC. Figure S24: ${ }^{1} \mathrm{H}$ NMR spectrum of $6(500 \mathrm{MHz}$, DMSO- $\left.d_{6}, 298 \mathrm{~K}\right)$. The symbols \# and $\sim$ indicate DMSO- $d_{6}$ and water residual peaks, respectively. Figure S25: ${ }^{13} \mathrm{C}$ NMR spectrum recorded for 6 (126 MHz, DMSO- $\left.d_{6}, 298 \mathrm{~K}\right)$. The symbol \# indicates DMSO- $d_{6}$ residual peak. Table S9: ${ }^{1} \mathrm{H}$ and ${ }^{13} \mathrm{C}$ NMR data obtained for 7 including key correlations determined from ${ }^{1} \mathrm{H}_{-}{ }^{1} \mathrm{H}$ COSY, ${ }^{1} \mathrm{H}_{-}{ }^{13} \mathrm{C}$ HSQC and ${ }^{1} \mathrm{H}_{-}{ }^{13} \mathrm{C}$ HMBC spectra. Figure S26: ${ }^{1} \mathrm{H}$ and $\left({ }^{13} \mathrm{C}\right)$ chemical shift values [ppm] and key correlations observed in NMR spectra of 7. Bold lines: ${ }^{1} \mathrm{H}-{ }^{1} \mathrm{H}$ COSY; Arrows: ${ }^{1} \mathrm{H}^{-13} \mathrm{C}$ HMBC. Figure S27: ${ }^{1} \mathrm{H}$ NMR spectrum of 7 (500 MHz, DMSO- $\left.d_{6}, 298 \mathrm{~K}\right)$. The symbols \# and $\sim$ indicate DMSO- $d_{6}$ and water residual peaks, respectively. Figure S28: ${ }^{13} \mathrm{C}$ NMR spectrum recorded for $7\left(126 \mathrm{MHz}, \mathrm{DMSO}-d_{6}, 298 \mathrm{~K}\right)$. The symbol \# indicates DMSO- $d_{6}$ residual peak. Table S10: ${ }^{1} \mathrm{H}$ and ${ }^{13} \mathrm{C}$ NMR data obtained for 8 including key correlations determined from ${ }^{1} \mathrm{H}-{ }^{1} \mathrm{H}$ COSY, ${ }^{1} \mathrm{H}^{13} \mathrm{C}$ HSQC and ${ }^{1} \mathrm{H}_{-}{ }^{13} \mathrm{C}$ HMBC spectra. Figure S29: ${ }^{1} \mathrm{H}$ and $\left({ }^{13} \mathrm{C}\right) \mathrm{chemical}$ shift values [ppm] and key correlations observed in NMR spectra of 8 . Bold lines: ${ }^{1} \mathrm{H}-{ }^{1} \mathrm{H}$ COSY; Arrows: ${ }^{1} \mathrm{H}-{ }^{13} \mathrm{C}$ HMBC. Figure S30: ${ }^{1} \mathrm{H}$ NMR spectrum of 8 (700 MHz, DMSO- $\left.d_{6}, 298 \mathrm{~K}\right)$. The symbols \# and indicate DMSO- $d_{6}$ and water residual peaks, respectively. Figure S31: ${ }^{13} \mathrm{C}$ NMR spectrum recorded for $8\left(176 \mathrm{MHz}, \mathrm{DMSO}-d_{6}, 298 \mathrm{~K}\right)$. The symbol \# indicates DMSO- $d_{6}$ residual peak. Figure S32: Synthetic approaches towards $\mathrm{A}_{3} \mathrm{~B}$ macrocycles: (i) 1,2-dicyanobenzene (tenfold excess), $(\mathrm{BuO})_{2} \mathrm{Mg}$, $\mathrm{BuOH}$, reflux, $20 \mathrm{~h}$.

Author Contributions: D.T.M., Conceptualization, Data Curation, Formal Analysis, Investigation, Methodology, Visualization, Writing-Original Draft, and Writing-Review and Editing; D.Z., Data curation, Formal Analysis, Investigation, Methodology, and Validation; E.K., Investigation, Methodology, Writing-Review and Editing; L.S., Conceptualization, Data Curation, Formal Analysis, Investigation, Methodology, Supervision, Validation, and Roles/Writing-Original Draft; T.K., Formal Analysis and Writing-Original Draft; J.M., Resources, Supervision, and Writing-Review and Editing; T.G., Formal Analysis, Funding Acquisition, Methodology, Project Administration, Resources, Supervision, and Writing-Review and Editing. All authors have read and agreed to the published version of the manuscript.

Funding: This research was funded by National Science Centre-Poland, grant number 2016/21/B/ NZ9/00783.

Institutional Review Board Statement: Not applicable.

Informed Consent Statement: Not applicable.

Data Availability Statement: The data presented in this study are available on request from the corresponding author.

Acknowledgments: The authors thank Beata Kwiatkowska and Rita Kuba for excellent technical assistance. D.T.M. would like to thank Agata Kaluzna-Mlynarczyk for her support. The authors thank the Poznan University of Medical Sciences Core Facility for providing access to equipment.

Conflicts of Interest: The authors declare no conflict of interest. The funders had no role in the design of the study; in the collection, analyses, or interpretation of data; in the writing of the manuscript, or in the decision to publish the results.

Sample Availability: Samples of the compounds 1-8 are available from the authors.

\section{References}

1. Rodríguez-Morgade, M.S.; Stuzhin, P.A. The chemistry of porphyrazines: An overview. J. Porphyrins Phthalocyanines 2004, 8 , 1129-1165. [CrossRef]

2. Falkowski, M.; Rebis, T.; Piskorz, J.; Popenda, L.; Jurga, S.; Mielcarek, J.; Milczarek, G.; Goslinski, T. Multiwalled carbon nanotube/sulfanyl porphyrazine hybrids deposited on glassy carbon electrode-Effect of nitro peripheral groups on electrochemical properties. J. Porphyrins Phthalocyanines 2017, 21, 295-301. [CrossRef]

3. Olgaç, R.; Baygu, Y.; Yıldız, B.; Gök, Y.; Köksoy, B.; Durmuş, M. Synthesis, characterization and photochemical properties of metallo porphyrazines substituted with alkyl linked carbazole, benzoazepine and phenothiazine moieties. J. Porphyrins Phthalocyanines 2017, 21, 599-610. [CrossRef]

4. Chełminiak-Dudkiewicz, D.; Ziegler-Borowska, M.; Stolarska, M.; Sobotta, L.; Falkowski, M.; Mielcarek, J.; Goslinski, T.; Kowalonek, J.; Wẹgrzynowska-Drzymalska, K.; Kaczmarek, H. The chitosan-Porphyrazine hybrid materials and their photochemical properties. J. Photochemistry Photobiol. B Biol. 2018, 181, 1-13. [CrossRef] 
5. Yang, C.; Gao, L.; Zhang, B.; Zhang, Z.; Deng, K. Uniform Zinc Thioporphyrazine nanosphere by self-assembly and the photocatalytic performance. J. Porphyrins Phthalocyanines 2018, 22, 868-876. [CrossRef]

6. Fernández-Ariza, J.; Urbani, M.; Rodríguez-Morgade, M.S.; Torres, T. Panchromatic photosensitizers based on push-pull, unsymmetrically substituted porphyrazines. Chem. Eur. J. 2018, 24, 2618-2625. [CrossRef]

7. Piskorz, J.; Lijewski, S.; Gierszewski, M.; Gorniak, K.; Sobotta, L.; Wicher, B.; Tykarska, E.; Düzgüneş, N.; Konopka, K.; Sikorski, M.; et al. Sulfanyl porphyrazines: Molecular barrel-like self-assembly in crystals, optical properties and in vitro photodynamic activity towards cancer cells. Dyes Pigment. 2017, 136, 898-908. [CrossRef]

8. Wöhrle, D.; Eskes, M.; Shigehara, K.; Yamada, A. A simple synthesis of 4,5-disubstituted 1,2-dicyanobenzenes and 2,3,9,10,16,17,23,24-octasubstituted phthalocyanines. Synthesis 1993, 1993, 194-196. [CrossRef]

9. Taşkın, G.C.; Durmuş, M.; Yüksel, F.; Mantareva, V.; Kussovski, V.; Angelov, I.; Atilla, D. Axially paraben substituted silicon(iv) phthalocyanines towards dental pathogen streptococcus mutans: Synthesis, photophysical, photochemical and in vitro properties. J. Photochem. Photobiol. A Chem. 2015, 306, 31-40. [CrossRef]

10. Masilela, N.; Kleyi, P.; Tshentu, Z.; Priniotakis, G.; Westbroek, P.; Nyokong, T. Photodynamic Inactivation of Staphylococcus Aureus Using Low Symmetrically Substituted Phthalocyanines Supported on a Polystyrene Polymer Fiber. Dyes Pigments 2013, 96, 500-508. [CrossRef]

11. Vashurin, A.; Kuzmin, I.; Mayzlish, V.; Razumov, M.; Golubchikov, O.; Koifman, O. Kinetics and mechanism of the oxidation of dithiocarbamic acids in the presence of Co(II) phthalocyaninetetacarboxylic acid. J. Serb. Chem. Soc. 2016, 81, 1025-1036. [CrossRef]

12. Vashurin, A.; Maizlish, V.; Kuzmin, I.; Znoyko, S.; Morozova, A.; Razumov, M.; Koifman, O. Symmetrical and difunctional substituted cobalt phthalocyanines with benzoic acids fragments: Synthesis and catalytic activity. J. Porphyrins Phthalocyanines 2017, 21, 37-47. [CrossRef]

13. Pires, I.S.; O'Boyle, Q.T.; Munoz, C.J.; Savla, C.; Cabrales, P.; Palmer, A.F. Enhanced photodynamic therapy using the apohemoglobin-haptoglobin complex as a carrier of aluminum phthalocyanine. ACS Appl. Bio Mater. 2020, 3, 4495-4506. [CrossRef]

14. Rak, J.; Pouckova, P.; Benes, J.; Vetvicka, D. Drug delivery systems for phthalocyanines for photodynamic therapy. Anticancer Res. 2019, 39, 3323-3339. [CrossRef]

15. Chrishtop, V.V.; Demidov, V.I.; Tomilova, I.K.; Nikonorova, V.G.; Tarasuk, I.A.; Botnar, A.A.; Vashurin, A.S.; Marfin, Y.S. Assessment of acute toxicity of cobalt tetrasulfophthalocyaninate by intravenous injection on Wistar rats. MHC 2020, 13, 7-12. [CrossRef]

16. Ghosh, S.; Carter, K.A.; Lovell, J.F. Liposomal formulations of photosensitizers. Biomaterials 2019, 218, 119341. [CrossRef]

17. Sobotta, L.; Skupin-Mrugalska, P.; Piskorz, J.; Mielcarek, J. porphyrinoid photosensitizers mediated photodynamic inactivation against bacteria. Eur. J. Med. Chem. 2019, 175, 72-106. [CrossRef]

18. Chelminiak-Dudkiewicz, D.; Rybczynski, P.; Smolarkiewicz-Wyczachowski, A.; Mlynarczyk, D.T.; Wegrzynowska-Drzymalska, K.; Ilnicka, A.; Goslinski, T.; Marszałł, M.P.; Ziegler-Borowska, M. Photosensitizing potential of tailored magnetite hybrid nanoparticles functionalized with levan and zinc (II) phthalocyanine. Appl. Surf. Sci. 2020, 524, 146602. [CrossRef]

19. Aksenova, N.A.; Savko, M.A.; Uryupina, O.Y.; Roldugin, V.I.; Timashev, P.S.; Kuz'min, P.G.; Shafeev, G.A.; Solov'eva, A.B. Effect of the preparation method of silver and gold nanoparticles on the photosensitizing properties of tetraphenylporphyrin-amphiphilic polymer-Nanoparticle systems. Russ. J. Phys. Chem. 2017, 91, 124-129. [CrossRef]

20. Bera, K.; Maiti, S.; Maity, M.; Mandal, C.; Maiti, N.C. Porphyrin-Gold nanomaterial for efficient drug delivery to cancerous cells. ACS Omega 2018, 3, 4602-4619. [CrossRef]

21. Setaro, F.; Wennink, J.W.H.; Mäkinen, P.I.; Holappa, L.; Trohopoulos, P.N.; Ylä-Herttuala, S.; van Nostrum, C.F.; de la Escosura, A.; Torres, T. Amphiphilic phthalocyanines in polymeric micelles: A supramolecular approach toward efficient third-generation photosensitizers. J. Mater. Chem. B 2020, 8, 282-289. [CrossRef]

22. Baugh, S.D.P.; Yang, Z.; Leung, D.K.; Wilson, D.M.; Breslow, R. Cyclodextrin dimers as cleavable carriers of photodynamic sensitizers. J. Am. Chem. Soc. 2001, 123, 12488-12494. [CrossRef]

23. Rotas, G.; Martín-Gomis, L.; Ohkubo, K.; Fernández-Lázaro, F.; Fukuzumi, S.; Tagmatarchis, N.; Sastre-Santos, Á. Axially substituted silicon phthalocyanine as electron donor in a dyad and triad with azafullerene as electron acceptor for photoinduced charge separation. Chem. A Eur. J. 2016, 22, 15137-15143. [CrossRef] [PubMed]

24. Mphuthi, N.G.; Adekunle, A.S.; Fayemi, O.E.; Olasunkanmi, L.O.; Ebenso, E.E. Phthalocyanine doped metal oxide nanoparticles on multiwalled carbon nanotubes platform for the detection of dopamine. Sci. Rep. 2017, 7, 43181. [CrossRef] [PubMed]

25. Liu, Q.; Yang, Y.; Lv, X.; Ding, Y.; Zhang, Y.; Jing, J.; Xu, C. One-step synthesis of uniform nanoparticles of porphyrin functionalized ceria with promising peroxidase mimetics for $\mathrm{h}_{2} \mathrm{O}_{2}$ and glucose colorimetric detection. Sens.Actuators B Chem. 2017, 240, 726-734. [CrossRef]

26. Dube, E.; Soy, R.; shumba, M.; Nyokong, T. Photophysicochemical behaviour of phenoxy propanoic acid functionalised zinc phthalocyanines when grafted onto iron oxide and silica nanoparticles: Effects in photodynamic antimicrobial chemotherapy. $J$. Luminescence 2021, 234, 117939. [CrossRef]

27. Ziental, D.; Czarczynska-Goslinska, B.; Mlynarczyk, D.T.; Glowacka-Sobotta, A.; Stanisz, B.; Goslinski, T.; Sobotta, L. Titanium dioxide nanoparticles: Prospects and applications in medicine. Nanomaterials 2020, 10, 387. [CrossRef] [PubMed] 
28. Musial, J.; Krakowiak, R.; Mlynarczyk, D.T.; Goslinski, T.; Stanisz, B.J. Titanium dioxide nanoparticles in food and personal care products-What do we know about their safety? Nanomaterials 2020, 10, 1110. [CrossRef]

29. Forsyth, T.P.; Williams, D.B.G.; Montalban, A.G.; Stern, C.L.; Barrett, A.G.M.; Hoffman, B.M. A facile and regioselective synthesis of trans-heterofunctionalized porphyrazine derivatives. J. Org. Chem. 1998, 63, 331-336. [CrossRef]

30. Linstead, R.P.; Whalley, M. 944. Conjugated macrocylces. Part XXII. Tetrazaporphin and its metallic derivatives. J. Chem. Soc. 1952, 4839-4846. [CrossRef]

31. Michel, S.L.J.; Hoffman, B.M.; Baum, S.M.; Barrett, A.G.M. Peripherally functionalized porphyrazines: Novel metallomacrocycles with broad, untapped potential. In Progress in Inorganic Chemistry; Karlin, K.D., Ed.; John Wiley \& Sons, Inc.: New York, NY, USA, 2002; pp. 473-590. ISBN 978-0471435105.

32. Arango, V.; Domínguez, J.J.; Cardona, W.; Robledo, S.M.; Muñoz, D.L.; Figadere, B.; Jairo Sáez, J. Synthesis and leishmanicidal activity of quinoline-triclosan and quinoline-eugenol hybrids. Med Chem Res 2012, 21, 3445-3454. [CrossRef]

33. Sułek, A.; Pucelik, B.; Kuncewicz, J.; Dubin, G.; Dąbrowski, J.M. Sensitization of $\mathrm{TiO}_{2}$ by halogenated porphyrin derivatives for visible light biomedical and environmental photocatalysis. Catalysis Today 2019, 335, 538-549. [CrossRef]

34. Oliveira, D.F.M.; Batista, P.S.; Muller, P.S.; Velani, V.; França, M.D.; de Souza, D.R.; Machado, A.E.H. Evaluating the effectiveness of photocatalysts based on titanium dioxide in the degradation of the dye ponceau 4R. Dyes Pigments 2012, 92, 563-572. [CrossRef]

35. Zhang, L.; Cole, J.M. Anchoring groups for dye-sensitized solar cells. ACS Appl. Mater. Interf. 2015, 7, 3427-3455. [CrossRef]

36. Altın, İ.; Sökmen, M.; Bıyıklığlu, Z. Quaternized zincv(II) phthalocyanine-sensitized $\mathrm{TiO}_{2}$ : Surfactant-modified sol-gel synthesis, characterization and photocatalytic applications. Desalination Water Treat. 2016, 57, 16196-16207. [CrossRef]

37. Fakayode, O.J.; Songca, S.P.; Oluwafemi, O.S. Singlet oxygen generation potential of thiolated methoxy-polyethyleneglycol encapsulated superparamagnetic iron oxide nanoparticles-gold core-shell meso-5, 10, 15, 20-tetrakis (4-hydroxyphenyl) porphyrin. Mater. Lett. 2017, 199, 37-40. [CrossRef]

38. Krakowiak, R.; Musial, J.; Frankowski, R.; Spychala, M.; Mielcarek, J.; Dobosz, B.; Krzyminiewski, R.; Sikorski, M.; BendzinskaBerus, W.; Tykarska, E.; et al. Phthalocyanine-grafted titania nanoparticles for photodegradation of ibuprofen. Catalysts 2020, 10, 1328. [CrossRef]

39. Kozlov, N.K.; Natashina, U.A.; Tamarov, K.P.; Gongalsky, M.B.; Solovyev, V.V.; Kudryavtsev, A.A.; Sivakov, V.; Osminkina, L.A. Recycling of silicon: From industrial waste to biocompatible nanoparticles for nanomedicine. Mater. Res. Express 2017, 4, 095026. [CrossRef]

40. Kasprzycki, P.; Sobotta, L.; Lijewski, S.; Wierzchowski, M.; Goslinski, T.; Mielcarek, J.; Radzewicz, C.; Fita, P. Unusual cisdiprotonated forms and fluorescent aggregates of non-peripherally alkoxy-substituted metallophthalocyanines. Phys. Chem. Chem. Phys. 2017, 19, 21390-21400. [CrossRef]

41. Khelevina, O.G.; Malyasova, A.S. 40 Years with porphyrazines. J. Porphyrins Phthalocyanines 2019, 23, 1251-1264. [CrossRef]

42. Stolarska, M.; Glowacka-Sobotta, A.; Mlynarczyk, D.T.; Dlugaszewska, J.; Goslinski, T.; Mielcarek, J.; Sobotta, L. Photodynamic activity of tribenzoporphyrazines with bulky periphery against wound bacteria. IJMS 2020, 21, 6145. [CrossRef]

43. Taştemel, A.; Karaca, B.Y.; Durmuş, M.; Bulut, M. Photophysical and photochemical properties of novel metallophthalocyanines bearing 7-Oxy-3-(m -methoxyphenyl) coumarin groups. J. Luminescence 2015, 168, 163-171. [CrossRef]

44. Kobayashi, N.; Sasaki, N.; Higashi, Y.; Osa, T. Regiospecific and nonlinear substituent effects on the electronic and fluorescence spectra of phthalocyanines. Inorg. Chem. 1995, 34, 1636-1637. [CrossRef]

45. Marini, A.; Muñoz-Losa, A.; Biancardi, A.; Mennucci, B. What is solvatochromism? J. Phys. Chem. B 2010, 114, 17128-17135. [CrossRef] [PubMed]

46. Isago, H.; Kagaya, Y.; Matsushita, A. Solvatochromic shift of phthalocyanine q-band governed by a single solvent parameter. Chem. Lett. 2004, 33, 862-863. [CrossRef]

47. Güzel, E.; Çetin, Ş.; Günsel, A.; Bilgiçli, A.T.; Şişman, İ.; Yarasir, M.N. Comparative studies of photophysical and electrochemical properties of sulfur-containing substituted metal-free and metallophthalocyanines. Res. Chem. Intermed. 2018, 44, 971-989. [CrossRef]

48. Sobotta, L.; Fita, P.; Szczolko, W.; Wrotynski, M.; Wierzchowski, M.; Goslinski, T.; Mielcarek, J. Functional singlet oxygen generators based on porphyrazines with peripheral 2,5-dimethylpyrrol-1-yl and dimethylamino groups. J. Photochem. Photobiol. A Chem. 2013, 269, 9-16. [CrossRef]

49. DeRosa, M.C.; Crutchley, R.J. Photosensitized singlet oxygen and its applications. Coord. Chem. Rev. 2002, 233, 351-371. [CrossRef]

50. Sobotta, L.; Dlugaszewska, J.; Gierszewski, M.; Tillo, A.; Sikorski, M.; Tykarska, E.; Mielcarek, J.; Goslinski, T. Photodynamic inactivation of enterococcus faecalis by non-peripherally substituted magnesium phthalocyanines entrapped in lipid vesicles. J. Photochem. Photobiol. B Biol. 2018, 188, 100-106. [CrossRef]

51. Gierszewski, M.; Falkowski, M.; Sobotta, L.; Stolarska, M.; Popenda, L.; Lijewski, S.; Wicher, B.; Burdzinski, G.; Karolczak, J.; Jurga, S.; et al. Porphyrazines with peripheral isophthaloxyalkylsulfanyl substituents and their optical properties. J. Photochem. Photobiol. A Chem. 2015, 307-308, 54-67. [CrossRef]

52. Piskorz, J.; Skupin, P.; Lijewski, S.; Korpusinski, M.; Sciepura, M.; Konopka, K.; Sobiak, S.; Goslinski, T.; Mielcarek, J. Synthesis, physical-chemical properties and in vitro photodynamic activity against oral cancer cells of novel porphyrazines possessing fluoroalkylthio and dietherthio substituents. J. Fluor. Chem. 2012, 135, 265-271. [CrossRef] 
53. Stolarska, M.; Glowacka-Sobotta, A.; Ziental, D.; Dlugaszewska, J.; Falkowski, M.; Mielcarek, J.; Goslinski, T.; Sobotta, L. Photochemical properties and photocytotoxicities against wound bacteria of sulfanyl porphyrazines with bulky peripheral substituents. J. Organomet. Chem. 2021, 934, 121669. [CrossRef]

54. Bonnett, R.; Martınez, G. Photobleaching of sensitisers used in photodynamic therapy. Tetrahedron 2001, 57, 9513-9547. [CrossRef]

55. Kuznetsova, N.A.; Kaliya, O.L. Oxidative photobleaching of phthalocyanines in solution. J. Porphyrins Phthalocyanines 2012, 16, 705-712. [CrossRef]

56. Dilber, G.; Altunparmak, H.; Nas, A.; Kantekin, H.; Durmuş, M. The peripheral and non-peripheral 2H-benzotriazole substituted phthalocyanines: Synthesis, characterization, photophysical and photochemical studies of zinc derivatives. Spectrochim. Acta Part A Molec. Biomolec. Spectrosc. 2019, 217, 128-140. [CrossRef]

57. Sergeeva, N.N.; Senge, M.O. Photochemical transformations involving magnesium porphyrins and phthalocyanines. In PATAI'S Chemistry of Functional Groups; Rappoport, Z., Ed.; John Wiley \& Sons, Ltd.: Chichester, UK, 2009; pp. 189-218. ISBN 9780470682531.

58. Słota, R.; Dyrda, G. UV Photostability of metal phthalocyanines in organic solvents. Inorg. Chem. 2003, 42, 5743-5750. [CrossRef]

59. Ogunsipe, A.; Maree, D.; Nyokong, T. Solvent effects on the photochemical and fluorescence properties of zinc phthalocyanine derivatives. J. Molec. Struct. 2003, 650, 131-140. [CrossRef]

60. Sobotta, L.; Lijewski, S.; Dlugaszewska, J.; Nowicka, J.; Mielcarek, J.; Goslinski, T. Photodynamic inactivation of enterococcus faecalis by conjugates of zinc (II) phthalocyanines with thymol and carvacrol loaded into lipid vesicles. Inorgan. Chim. Acta 2019, 489, 180-190. [CrossRef]

61. Ogunsipe, A.; Durmuş, M.; Atilla, D.; Gürek, A.G.; Ahsen, V.; Nyokong, T. Synthesis, photophysical and photochemical studies on long chain zinc phthalocyanine derivatives. Synth. Metals 2008, 158, 839-847. [CrossRef]

62. Mlynarczyk, D.T.; Lijewski, S.; Falkowski, M.; Piskorz, J.; Szczolko, W.; Sobotta, L.; Stolarska, M.; Popenda, L.; Jurga, S.; Konopka, K.; et al. Dendrimeric sulfanyl porphyrazines: Synthesis, physico-chemical characterization, and biological activity for potential applications in photodynamic therapy. ChemPlusChem 2016, 81, 460-470. [CrossRef]

63. Johnson, B.T. Microtox®acute toxicity test. In Small-Scale Freshwater Toxicity Investigations: Toxicity Test Methods; Blaise, C., Férard, J.F., Eds.; Springer: Dordrecht, The Netherlands, 2005; pp. 69-105. ISBN 978-1402031205.

64. Niemirycz, E.; Nichthauser, J.; Staniszewska, M.; Nałęcz-Jawecki, G.; Bolałek, J. The microtox®biological test: Application in toxicity evaluation of surface waters and sediments in Poland. Oceanol. Hydrobiol. Stud. 2007, 36, 151-163. [CrossRef]

65. Daghrir, R.; Dimboukou-Mpira, A.; Seyhi, B.; Drogui, P. Photosonochemical degradation of butyl-paraben: Optimization, toxicity and kinetic studies. Sci. Total Environ. 2014, 490, 223-234. [CrossRef]

66. Seotsanyana-Mokhosi, I.; Kuznetsova, N.; Nyokong, T. Photochemical studies of tetra-2, 3-pyridinoporphyrazines. J. Photochem. Photobiol. A Chem. 2001, 140, 215-222. [CrossRef]

67. Kuznetsova, N.A.; Okunchikov, V.V.; Derkacheva, V.M.; Kaliya, O.L.; Lukyanets, E.A. Photooxidation of metallophthalocyanines: The effects of singlet oxygen and PcM-O 2 complex formation. J. Porphyrins Phthalocyanines 2005, 9, 393-397. [CrossRef]

68. Kuznetsova, N.A.; Makarov, D.A.; Yuzhakova, O.A.; Solovieva, L.I.; Kaliya, L.O. Study on the photostability of water-soluble Zn (II) and $\mathrm{Al}$ (III) phthalocyanines in aqueous solution. J. Porphyrins Phthalocyanines 2010, 14, 968-974. [CrossRef]

69. Chauke, V.; Ogunsipe, A.; Durmuş, M.; Nyokong, T. Novel gallium (III) phthalocyanine derivatives-Synthesis, photophysics and photochemistry. Polyhedron 2007, 26, 2663-2671. [CrossRef]

70. Lü, X.; Li, J.; Wang, C.; Duan, M.; Luo, Y.; Yao, G.; Wang, J.L. Enhanced photoactivity of CuPp-TiO 2 photocatalysts under visible light irradiation. Appl. Surf. Sci. 2010, 257, 795-801. [CrossRef] 